Review

\title{
Respiratory syncytial virus: from pathogenesis to potential therapeutic strategies
}

\author{
Zifang Shang ${ }^{1,2}$, Shuguang Tan², Dongli Ma1 ${ }^{\boxplus}$ \\ 1. Institute of Pediatrics, Shenzhen Children's Hospital, 518026 Shenzhen, Guangdong Province, China. \\ 2. CAS Key Laboratory of Pathogenic Microbiology and Immunology, Institute of Microbiology, Chinese Academy of Sciences, 100101Beijing, China. \\ $\triangle$ Corresponding author: E-mail: mad11234@126.com.
}

() The author(s). This is an open access article distributed under the terms of the Creative Commons Attribution License (https://creativecommons.org/licenses/by/4.0/). See http://ivyspring.com/terms for full terms and conditions.

Received: 2021.07.09; Accepted: 2021.09.18; Published: 2021.09.27

\begin{abstract}
Respiratory syncytial virus (RSV) is one of the most important viral pathogens causing respiratory tract infection in infants, the elderly and people with poor immune function, which causes a huge disease burden worldwide every year. It has been more than 60 years since RSV was discovered, and the palivizumab monoclonal antibody, the only approved specific treatment, is limited to use for passive immunoprophylaxis in high-risk infants; no other intervention has been approved to date. However, in the past decade, substantial progress has been made in characterizing the structure and function of RSV components, their interactions with host surface molecules, and the host innate and adaptive immune response to infection. In addition, basic and important findings have also piqued widespread interest among researchers and pharmaceutical companies searching for effective interventions for RSV infection. A large number of promising monoclonal antibodies and inhibitors have been screened, and new vaccine candidates have been designed for clinical evaluation. In this review, we first briefly introduce the structural composition, host cell surface receptors and life cycle of RSV virions. Then, we discuss the latest findings related to the pathogenesis of RSV. We also focus on the latest clinical progress in the prevention and treatment of RSV infection through the development of monoclonal antibodies, vaccines and small-molecule inhibitors. Finally, we look forward to the prospects and challenges of future RSV research and clinical intervention.
\end{abstract}

Key words: Respiratory syncytial virus, Pathogenesis, Infection, Intervention, Antibody, Vaccine

\section{Introduction}

RSV was first isolated from chimpanzees with respiratory diseases in 1955 [1]. In 1957, the virus was isolated from babies with severe lower respiratory tract diseases [2]. Since then, RSV has been proven to be a ubiquitous pathogen, causing a great burden of disease on children, the elderly and high-risk adults. In particular, almost all children younger than 2 years old will be infected, and one-half of these children will be infected twice during this period [3]. Globally, RSV causes approximately 60,000 deaths of hospitalized children younger than 5 years old each year [4]. It is the leading cause of infant hospitalization in the world and the second leading cause of infant death after malaria. Over the years, scientists' continued awareness of the serious threat posed by respiratory syncytial virus has inspired researchers, including those in pharmaceutical companies, to develop effective interventions.

RSV is a polymorphic negative sense, single-stranded RNA virus belonging to the Orthopneumovirus genus of the family Pneumoviridae in the order Mononegavirales [5]. The virus is mainly transmitted by close contact with saliva or mucus droplets. After the virus replicates in the epithelial cells of the nasopharynx and upper respiratory tract for a short time, the released virus particles may transfer to the bronchioles or alveoli of the lower respiratory tract. The immune response in patients infected with RSV causes neutrophils to infiltrate and narrow the airways, leading to respiratory diseases such as bronchiolitis. In general, approximately 3 to 7 days after being infected, 
patients begin to develop some common symptoms, including fever, runny nose, stuffy nose, cough, and chest tightness [6].

Currently, there is no effective means for the prevention and treatment of RSV infection has been approved, but in the past decade, dozens of candidates for the prevention and treatment of RSV diseases have been screened under great continuous efforts (particularly in structural biology and single B cell techniques). More than 30 different candidate vaccines and more than 10 kinds of antibodies are in clinical or preclinical development. These promising prevention and treatment methods will effectively improve some deleterious effects of infection, such as vaccine-enhanced diseases caused by RSV infection in the early stage and the shortened half-life of RSV antibodies in the human body. Some of the iconic events in the study against RSV infection since RSV discovery are listed in Figure 1 below.

In this review, we briefly describe the structure of RSV virions, the latest progress in understanding host surface virus-binding receptors and the viral life cycle. Then, we discuss recent advances in understanding the pathogenesis of RSV infection. We also highlight the latest progress in the prevention and treatment of RSV infection, including the development of vaccines, monoclonal antibodies and small-molecule fusion inhibitors. Finally, we look forward to the prospects of RSV research and clinical intervention in the future.

\section{Genome structure, entry and the life cycle}

\section{The virion genome structure}

Human RSV is mainly composed of two subtypes (A and B), which belong to the Orthopneumovirus genus in the Pneumoviridae family and Mononegavirales order, and is prone to genetic changes. In terms of structural morphology, RSV is a pleomorphic virus particle in which the filovirus is the dominant form, with a diameter of approximately 50 $\mathrm{nm}$ and a length from 1 to $10 \mu \mathrm{m}$, while the spherical virus particle is generally from 150 to $250 \mathrm{~nm}$ in diameter [5].

The virion contains an unsegmented, single-stranded, antisense viral RNA genome of approximately $15.2 \mathrm{~kb}$. The full-length genome is segmented into 10 genes encoding 2 nonstructural proteins and 9 structural proteins (a total of 11 proteins; Figure 2). The nonstructural proteins NS1

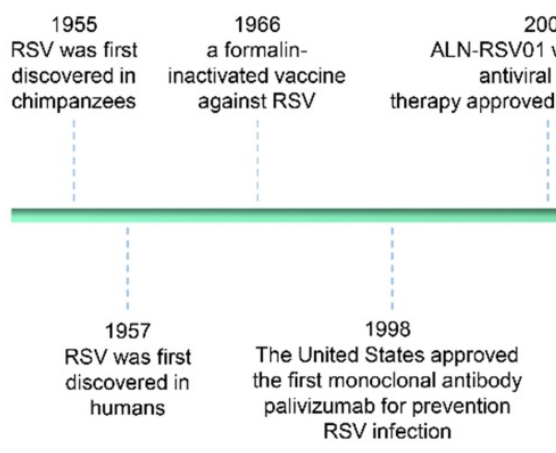

013
of the RSV F
the prefusion protein in the prefusion
form was resolved

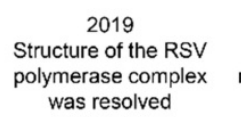
was resolved

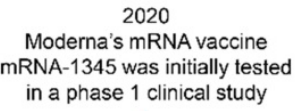

Figure 1. Timeline of RSV discovery and important related events.

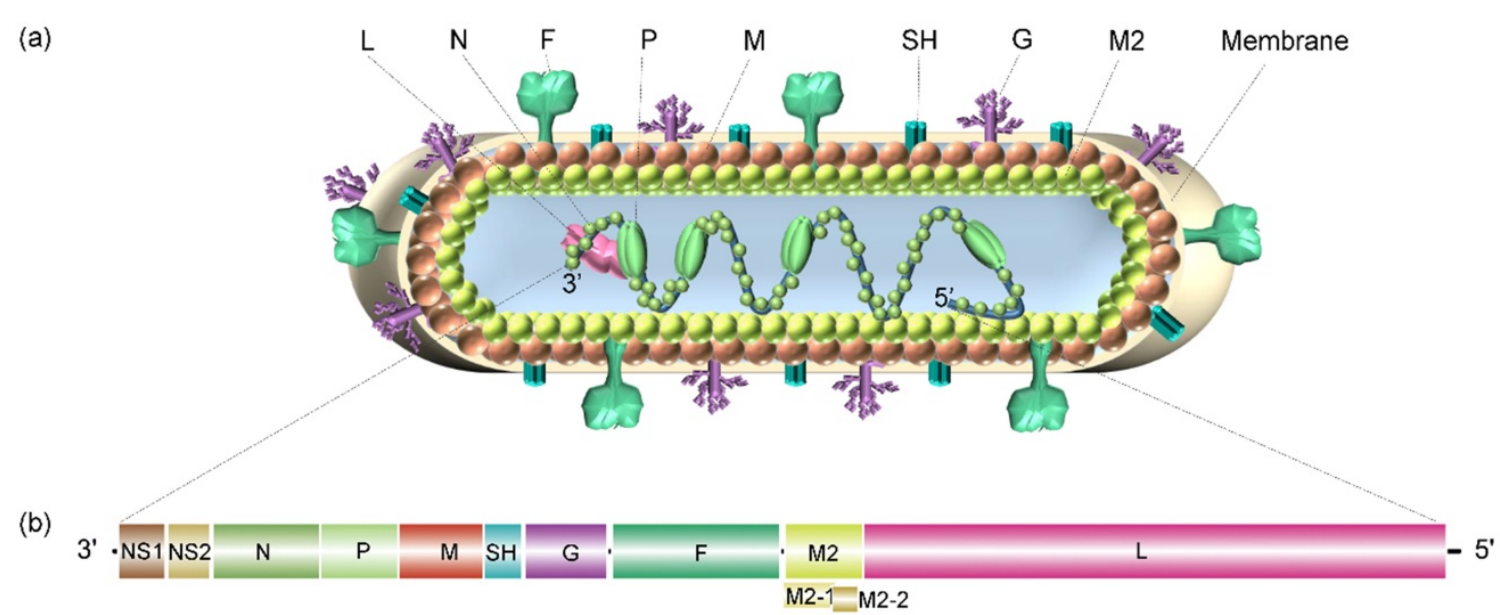

Figure 2. Schematic diagram of the RSV virion and its genome structure. (a) The general structure of the RSV virion and its encoded proteins. (b) The genome organization of RSV consists of 11 open reading frames (ORFs), including 2 ORFs adjacent to the $3^{\prime}$ leader region that encode nonstructural proteins related to evading the innate immune response, and ORFs that encode structural proteins: nucleoprotein $(\mathrm{N})$, phosphoprotein $(\mathrm{P})$, matrix protein $(\mathrm{M})$, small hydrophobic $(\mathrm{SH})$ protein, glycoprotein $(\mathrm{G})$, fusion protein (F), M2 protein, and polymerase (L) protein. 
and NS2 are primarily described as being related to evasion from the innate immune response, in which the unique structural region of NS1 is involved in the regulation of the host response, including inhibition of the type I interferon (IFN) response, inhibition of dendritic cell maturation and promotion of the inflammatory response [7]. NS2 can bind and inhibit the ubiquitination of inactive forms of retinoic acid-inducible gene-I (RIG-I) and melanoma differentiation-associated protein 5 (MDA5) and prevent the production of downstream signals and type I IFN [8].

The nucleoprotein $(\mathrm{N})$ is critical for tight viral binding to genomic RNA. Phosphoprotein (P) is an important polymerase cofactor that forms tetramers [9], which acts not only as a cofactor of $\mathrm{N}$ protein monomers and connects the $\mathrm{L}$ protein to the nucleoprotein-ribonucleic acid complex [10] but also as a chaperone protein to prevent the binding of newly synthesized $\mathrm{N}$ protein to host cell RNA [11]. The matrix protein $(\mathrm{M})$ is located inside the viral envelope and plays a role in supporting the viral envelope. Additionally, it participates in the transcription process of viral RNA. The small hydrophobic $(\mathrm{SH})$ protein is a pentameric ion channel that is thought to be related to the delayed apoptosis of infected cells [12]. Glycoprotein $(G)$ is rich in serine and threonine $(\sim 30-35 \%)$ and proline residues $(\sim 8-10 \%)$. After translation, this viral glycoprotein is modified into a highly glycosylated protein with 4-5 $\mathrm{N}$ - and 30-40 O-linked sugars, which account for approximately $60 \%$ of the molecular weight of these mature glycoproteins [13]. As an attachment protein, this glycoprotein connects virions to target cells by interacting with host cell surface molecules. In addition to the membrane-bound form, this viral $G$ protein is also produced in a secretory soluble form upon alternative translation of the second AUG codon (M48) in the ORF, which is located in the TM domain. Then, the N-terminus is hydrolyzed and modified to form a new N-terminus. Although both the membrane and secretory forms mediate the immune escape of RSV, the soluble form also induces the production of specific antibodies targeting the viral $G$ protein and reduces the antiviral activity of leukocytes that are mediated by the fragment crystallizable region $(\mathrm{Fc})[14,15]$. The $\mathrm{G}$ protein is disordered and consists of an N-terminal hydrophobic transmembrane domain (approximately 40-65 amino acids) and a C-terminal extracellular domain (approximately 66-298 amino acids). There is a short central conserved region (CCR) in the extracellular domain of viral $G$, which is sandwiched between two "mucin-like" regions (determining the antigenic subgroups A and B) flanking both sides of the protein [16]. The CCR contains a cystine knot and four cysteines that form two disulfide bonds with 1-4 and 2-3 topologies $[17,18]$. Altogether, viral $G$ has a high degree of sequence variation within and between virus species. Fusion protein $(\mathrm{F})$ is synthesized into a precursor (F0) containing 574 amino acids, which is then cleaved by a host cell protease to produce a heterodimer connected by disulfide bonds formed between F1 and F2 subunits accompanied by the release of the p27 peptide. Then, a mature $\mathrm{F}$ protein trimer form is formed to mediate the fusion of the virus membrane and the host cell membrane [19]. In addition, the F protein is also critical for the fusion of infected cells with neighboring cells, thus forming a unique syncytium. The M2 gene has two overlapping ORFs producing the M2-1 and M2-2 protein. The former is a factor involved in the transcription process [20], and the latter is a protein that regulates the transition from transcription to genome replication. The $\mathrm{L}$ protein contains three conserved enzymatic domains: an RNA-dependent RNA polymerase (RdRp) domain, a polyribonucleotide transferase (PRNTase or capping) domain and a methyltransferase (MTase) domain, which catalyzes cap methylation [9]. RdRp initiates two RNA synthesis processes induced by viral promoters: genomic replication at position $1 \mathrm{U}$ and mRNA transcription at position 3C. A single promoter can be initiated directly from positions $1 U$ and $3 C$ independently of each other, and the same RdRp can accurately select both of these sites. RdRp tends to start at 3C, but the selection of initiation sites may be regulated by the relative concentrations of ATP and GTP [21].

\section{Entry of RSV and its host binding receptors}

The process by which RSV virions enter host cells is primarily initiated by the binding of virions to the surface molecules of host cells and the fusion of the virus and host cell membranes. As mentioned in the previous section, three structural proteins are encoded to localize to the surface of the virus: $\mathrm{SH}, \mathrm{G}$ and F. The RSV SH protein is not necessary for in vitro infection [22]. Therefore, in the following sections, we focus on substantial advances in the understanding of the interaction of RSV G and F proteins with a host cell. Figure 3 shows a schematic diagram of RSV binding to potential receptors in host cells.

The main function of the viral $G$ protein is to bind virions to the cell surface by interacting with host cell adhesion molecules. Annexin II is a peripheral membrane protein expressed on endothelial cells in a variety of tissues and organs that participates in many activities located on the cell surface. For example, annexin II binds to phospholipids on the surface of 
EGTA-treated endothelial cells with high affinity in a calcium-dependent manner. On the surface of metastatic lymphoma cells, annexin II seems to enhance the cancer cells adhesion to hepatic sinusoid endothelial cells [23]. In addition, the extracellular matrix component tenascin $\mathrm{C}$ strongly binds to annexin II on gliomas and endothelial cells and initiates migration, cell proliferation and loss of focal adhesion [24]. As a potential RSV receptor, annexin II has been found to bind to the RSV G protein in Hep2 cells, which can be inhibited by the selectin antagonist TBC1269 [25]. Heparan sulfate proteoglycan (HSPG) and other glycosaminoglycans (GAGs) on the surface of host cells seem to promote the infection of RSV in immortalized cell lines, which may be realized by the promoted binding of positively charged residues in the heparin-binding domain (HBD) of the RSV G protein [26]. Notably, in infected Hep-2 cells, the molecular weight of the $G$ protein expressed by an RSV virion is $95 \mathrm{kDa}$ after glycosylation, and the molecular weight of its polypeptide skeleton is 32 $\mathrm{kDa}$. However, a $\mathrm{G}$ protein with higher glycosylation levels and a greater molecular weight, $170 \mathrm{kDa}$, was produced in HBE culture, in which virions of both laboratory-adapted strains and clinical isolates of RSV subgroups A and B were evident [27]. However, the absence of HSPG on the surface of human ciliated airway epithelial cells greatly eliminated the interaction between G and HSPG in these cells [28]. In contrast, CX3C chemokine receptor 1 (CX3CR1) on the apical surface of ciliated cells in human airway epithelial (HAE) culture binds to CX3CL1 and mediates its adhesion and migration. A study confirmed the interaction between host CX3CR1 and RSV G. A non-neutralizing monoclonal antibody

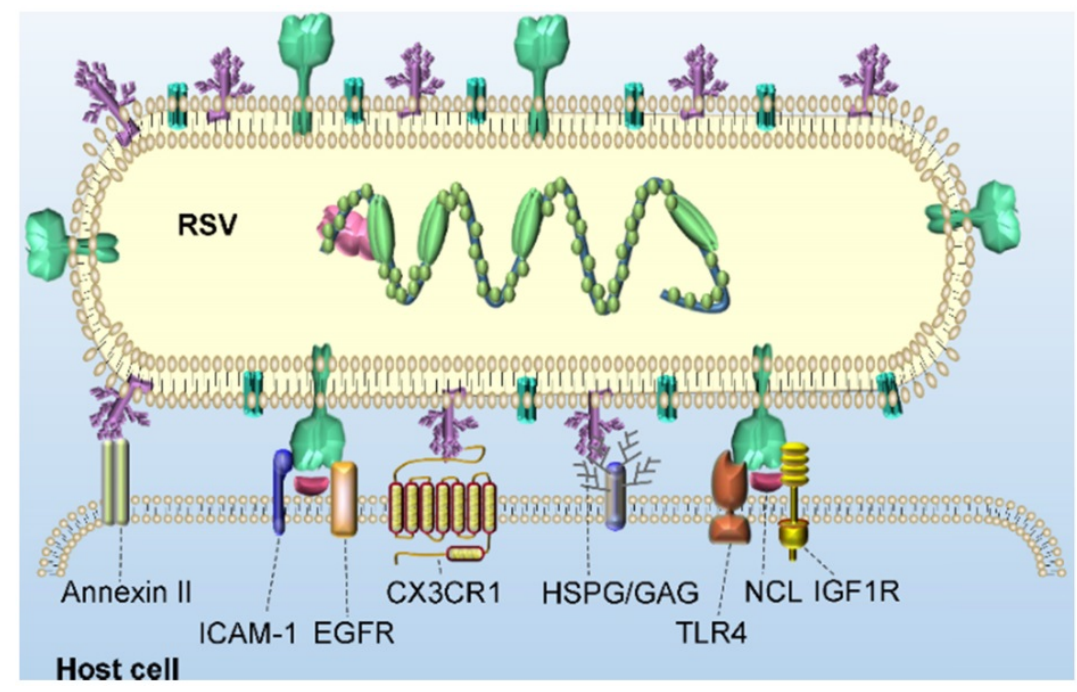

Figure 3. Potential receptors of RSV binding for virus entry into host cells. Potential receptors, such as annexin II, HSPG/GAG and CX3CR 1, bind to the RSV G glycoprotein, and TLR4, ICAM-1, EGFR, NCL and IGFIR bind to the RSV F glycoprotein, tether RSV virions to the cell surface.
$(\mathrm{mAb})$ against the $\mathrm{CX} 3 \mathrm{C}$ motif of the viral $\mathrm{G}$ protein could inhibit the effective infection of RSV in culture. In addition, CX3CR1-deficient mice were significantly less susceptible to RSV infection than CX3CR1expressing mice [29].

Another major glycoprotein on the surface of RSV is the F protein, which is a class I fusion protein. The F protein is anchored on the surface of the RSV membrane by a transmembrane domain and is a 'spring-loaded' trimer. Extensive and in-depth studies have been carried out on the binding receptors of the F protein. Toll-like receptor 4 (TLR4), a pattern recognition receptor (PRR) member of the Toll-like receptor family, is known as a sensitive receptor of gram-negative lipopolysaccharide (LPS). It has been shown to mediate the activation of the intracellular NF-kB signaling pathway and inflammatory cytokines to trigger the innate immune system [30]. RSV replicating in higher concentrations in TLR4-deficient mice persisted longer than that replicating in normal mice. This finding suggests that the expression of TLR4 plays an important role in controlling RSV replication in vivo and mediates the innate immune response of monocytes to produce IL-6 upon exposure to the RSV F protein [31]. Intercellular adhesion molecule-1 (ICAM-1), a type 1 glycoprotein in the immunoglobulin superfamily, promotes the entry and infection of RSV in human epithelial cells by binding to RSV F protein, which is important for viral replication and infection [32]. In addition, it has been reported that epidermal growth factor receptor (EGFR) expressed on the apical surface of differentiated bronchial epithelial cells can interact with the RSV F protein and promote fusion of host-virus membrane [33]. Tayyari et al. found that RSV interacted with nucleolin (NCL) of host cells via the $\mathrm{F}$ protein and specifically bound to NCL on the surface of apical cells in vitro. Confocal microscopy showed that NCL and RSV virions were colocalized at the surface of the cultured cells. When these cells were preincubated with NCL-specific antibodies, the colocalization of RSV and NCL proteins on the cell surface decreased significantly [34]. Another study found that the levels of NCL and TLR4 colocalized with the F protein increased in the early stage of infection and then decreased. Although NCL is the most widely studied of the potential receptors described above, it has also been shown to interact with many other viruses, including HIV-1 [35], human parainfluenza virus type 3 [36], 
enterovirus71 [37], human influenza A [38] and rabbit hemorrhagic disease virus [39]. These findings seem to suggest that NCL may act as a cofactor of the RSV F protein not as a major binding receptor. Most recently, Griffiths et al. discovered insulin-like growth factor 1 receptor (IGF1R) as a novel receptor of RSV [40], which may provide a new insight for the entry of RSV into the host.

An endocytic entry mechanism is initiated of RSV G protein. RSV infection activates ATPase $\mathrm{Na}^{+} / \mathrm{K}^{+}$transporting subunit alpha 1 (ATP1A1) in an RSV G protein-dependent manner, which in turn causes tyrosine kinase c-Src to transactivate EGFR through phosphorylation at EGFR Tyr845 [41]. The downstream signals of EGFR lead to actin rearrangement, wrinkles on the plasma membrane and phagocytosis of liquid and RSV via macropinosomes upon extension of the plasma membrane. RSV is introduced into large liquid-filled macropinosomes in the form of the viral envelope, which eventually promotes the fusion of RSV and host membranes and RSV entry into the host cell. San-Juan-Vergara et al. indicated that in primary NHEB cells, the entry of RSV is caused by the binding of RSV to cholesterol-rich plasma membrane components that promote the semifusion of the RSV envelope and the plasma membrane with complete fusion following in the endosome during endocytosis [26]. Krzyzaniak et al. believe that the entry of RSV virions involves the interaction between the RSV F protein and EGFR that activates the signal cascade of phosphatidylinositol 3-kinase (PI3K), p21-activated kinase 1 (PAK1) and downstream effectors in host cells. They content that this signaling cascade leads to a series of disturbances, such as actin rearrangement, plasma membrane vesicle formation, and a significant increase in fluid uptake, triggering macrophage-mediated endocytosis. In the macropinosomes in which Rab5 functions, the RSV F protein is cleaved for a second time under the action of an acid-independent furin-like enzyme and ultimately enters the host effectively [42]. Recently, Griffiths et al. suggested that the binding of the RSV F glycoprotein to IGF1R triggers the activation of protein kinase $\mathrm{C} \zeta$ (PKC zeta), which then promotes the recruitment of NCL from the nucleus to the plasma membrane, thus enhancing the binding and entry of RSV virions to host cells [40]. The related experiments showed that inhibition of PKC $\zeta$ significantly reduced RSV infection to the same extent as blocking the interaction between RSV and NCL.

\section{The life cycle of RSV}

Once the virion binds and enters a host cell, internal viral components are released. The viral ribonucleoprotein (RNP) complex assembled by L polymerase and viral genomic RNA wrapped by $\mathrm{P}$, M2-1 and N proteins is replicated, transcribed and translated into the various components needed to form viral progeny in a space called the cytoplasmic protein inclusion body (IB) near the intima [43]. The IB contains some host proteins, such as the antiviral protein MDA5 [44], chaperone protein HSP70 [45], poly(A)-binding protein (PABP) and eukaryotic translation initiation factor 4G (EIF4G) [43]. Because RSV is a negative sense RNA virus, the RSV genome contains noncoding regions, namely, the leader region and tailer region, at the $3^{\prime}$ and $5^{\prime}$ ends, respectively. RdRp not only replicates and synthesizes full-length and positive-sense antigenomes but also transcribes viral subgenomic mRNA (Figure 4). Currently, the mechanism by which the polymerase complex switches between replication and transcription has not been elucidated. It has been reported that this switching may be related to the M2-2 protein because its deletion significantly reduced the level of genomic and antigenomic RNA in infected cells [46]. Subsequently, the RNP complex is thought to use the trailer region as a promoter to replicate the full-length negative-sense genome at the $3^{\prime}$ end of the positive-sense antigenome for the assembly of progeny viruses. In this process of genome transcription, RSV polymerase initially binds a sequence from the polymerase starting point of the leader region (nucleotides 1 to 15) and moves along the RNA genome from the $3^{\prime}$ end to the $5^{\prime}$ end to produce all 10 subgenomic mRNAs. There are gene start (GS) and gene end (GE) signals on both sides of the template gene region corresponding to each newly synthesized mRNA $[47,48]$. The GS signal guides the polymerase to initiate mRNA synthesis and adds a methylated guanosine cap structure to the 5 ' end of the newly synthesized mRNA. The GE signal guides the addition of a poly A sequence at the $3^{\prime}$ end and induces the release of the mRNA [48]. Subsequently, the polymerase continues to slide along the gene sequence after the GE signal until the next GS signal is activated to synthesize the next subgenomic mRNA. Both genomic and antigenomic RNA are directly encapsulated by nuclear protein $(\mathrm{N})$ in the process of synthesis, and each $\mathrm{N}$ protein binds 7 nucleotides.

RSV glycoproteins are initially translated into the endoplasmic reticulum and then transported to the Golgi apparatus, where they are glycosylated and rapidly expanded along microtubules to form filaments through dynein-dependent vesicles. The RNP complex loaded with the RSV RNA genome is assembled into filaments after their formation and ultimately transferred to the plasma membrane to sprout new RSV virus particles [49]. However, Ke et 
al. performed by cryo-electron tomography to find that the assembly of RSV virions occurred at the plasma membrane [5]. When RSV is newly released from infected cells, it is filamentous regardless of virus strain, cell line or the polarization phenotype of the host cell. This characterization is obviously different than that of influenza virus. The morphology of influenza virions is closely related to the polarization phenotype of the host cell and the integrity of its actin microfilaments. When influenza strain A/Udorn/72 is produced in infected polarized epithelial cells, it is filamentous, but in nonpolarized cell types, almost all the virions produced are spherical [50].

\section{Pathogenesis}

RSV is mainly transmitted from person to person through saliva or mucus droplets. Symptoms begin approximately 3 to 7 days after infection with RSV and include fever, runny or stuffy nose, cough, chest tightness, wheezing and dyspnea [6]. Notably, when an infected person coughs or sneezes, vesicles from extracellular amoebae, among the most common organisms in relatively humid environments, may contribute to the persistence of respiratory viruses in the environment [51]. RSV infection can induce microtubule-/dynein-dependent mitochondria to gather around the nucleus and translocate to the center of the microtubule tissue [52]. These changes lead to impairment of mitochondrial respiratory function, loss of mitochondrial membrane potential and elevation of mitochondrial reactive oxygen species (ROS), which in turn increase the replication and titer of RSV. In addition, RSV infection can stabilize the expression of hypoxia-inducible factor-1a (HIF-1a) in infected cells, which profoundly changes cell metabolism to facilitate glycolysis and the pentose phosphate pathway activation and further enhance the replication ability of RSV [53].

RSV infection is most likely to affect the respiratory system, with most of the damage to the airway mediated by the immune response, not by the virus replication itself. The main cell to be infected by RSV is the respiratory epithelial cell (AEC). In AEC, RSV F inhibits the production of interferon- $\lambda$ (IFN- $\lambda$ ) induced by interferon regulatory factor (IRF) 1 (the most critical type III IFN in the antiviral immune response to RSV infection) by inducing EGFR activation, which leads to a continuous increase in viral infection [54]. In infected cells, the transcription of viral genes should encode NS1 and NS2 proteins initially, which are essential for host infection, and their function is to inhibit the type I interferon (IFN-I) response and other components of the immune system. NS1, which has previously been studied more deeply than NS2, is a major participant in

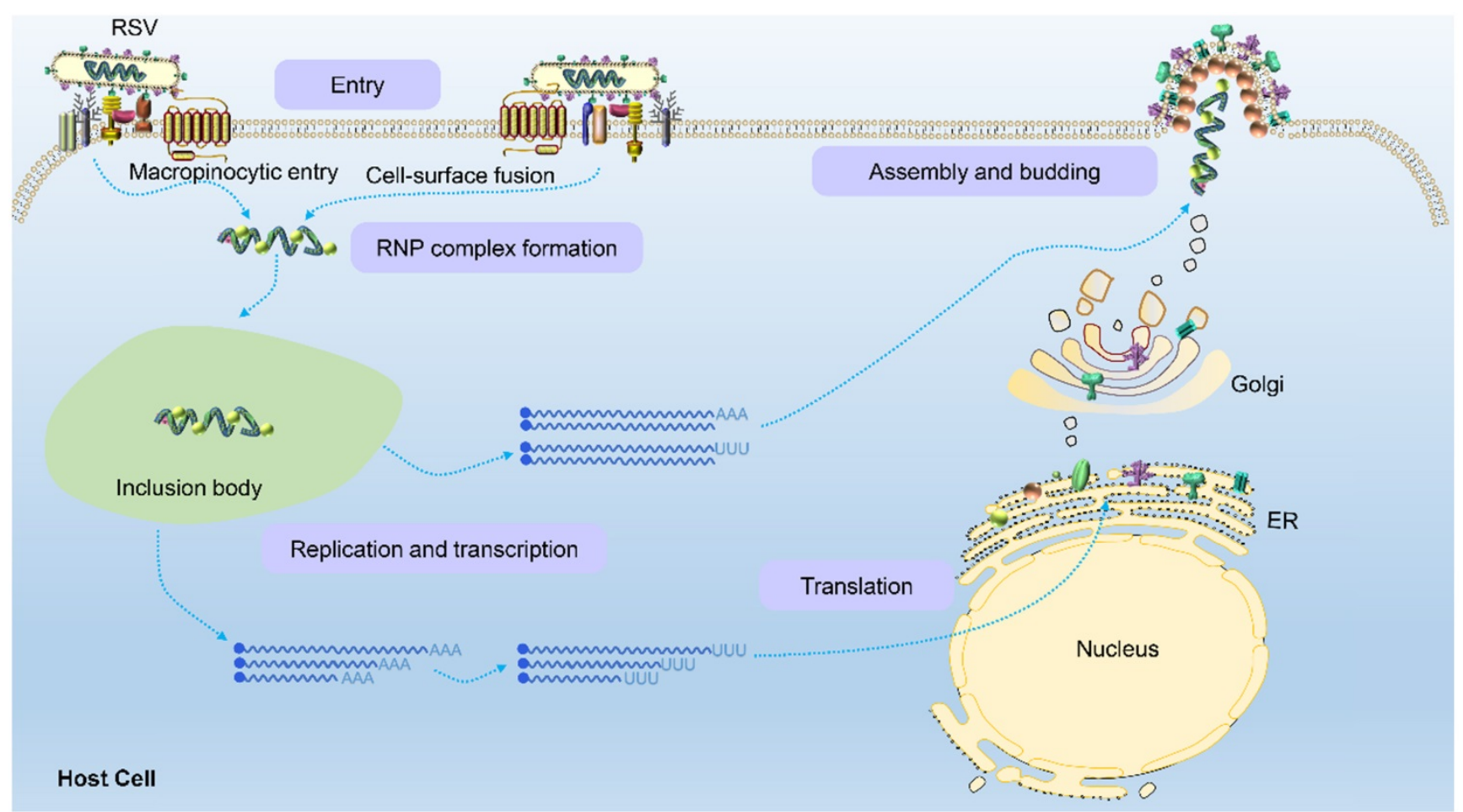

Figure 4. Schematic of the RSV life cycle. RSV first enters the host cell via macropinocytosis or cell-surface fusion by binding to the host cell receptor. The virus fuses with the cell membrane and releases the RNP complex to initiate replication and transcription in an inclusion body to produce the genomes, internal component proteins, and surface proteins required by the virus. Genomes are assembled to form new RNP complexes, and proteins are translated on the endoplasmic reticulum and then moved to the Golgi apparatus where they mature. Finally, the RNP complexes are transferred to the plasma membrane to germinate new filamentous RSV virions, completing the viral life cycle. 
immunosuppression. It is reported that NS1 can bind and inhibit various molecules in the signal cascade of IFN-I response in retinoic acid-inducible gene I (RIG-I) or Toll-like receptor (TLR) pathway [55]. The NS1 and NS2 complexes are transported to mitochondria to form degradosome, which can degrade a variety of proteins in the IFN-I pathway [56-58], such as STAT2, TRAF3 (TNF receptor-associated factor 3), TBK1 (TANK-binding kinase 1) and RIG-I. NS1 protein also plays a role in altering $\mathrm{CD}^{+} / \mathrm{CD}^{+}$cells. On the one hand, NS1 inhibits the activation and proliferation of $\mathrm{CD}_{103^{+}}$ CD8 ${ }^{+} \mathrm{T}$ cells, in which CD103 is a molecule that guides $\mathrm{CD}^{+} \mathrm{T}$ cells to respiratory mucosal epithelial cells and triggers cytolytic activity [59]. At the same time, NS1 also inhibited the activation and proliferation of Th17 cells with antiviral effect. On the other hand, NS1 increased the expression of IL-4 in CD4 $4^{+} \mathrm{T}$ cells and promoted the response of Th2 (T helper cells) by antagonizing IFN-I [59].

IL-33 signaling has been shown to play an important role in airway inflammation caused by RSV infection [60], and neutralizing IL-33 can significantly reduce the occurrence of allergic inflammatory events $[61,62]$. A variety of cell-derived (such as alveolar macrophages and dendric cells) IL-33 can be triggered in the process of RSV infection [60,63], which is thought to depend on the activation of MAPK signaling pathway [64], and then induce the release of nuclear factor-kappa B (NF-kB) and IRF from alveolar macrophages and mast cells during the innate immune response, resulting in the production of IL-6 and tumor necrosis factor- $\alpha$ (TNF-a), which lead to the secretion of tissue mucus. The accumulation of these inflammatory factors further recruits a large number of granulocytes (such as neutrophils) to the infected site. A recent study showed that neutrophils could significantly regulate RSV latent infection and reduce the exacerbation of asthma in children through phagocytosis facilitated by the carcinoembryonic antigen-associated cell adhesion molecule 3 (CEACAM3) protein [65]. Recruitment of neutrophils in the airway of patients can increase the expression of some bactericidal proteins, such as myeloperoxidase (MPO) and bactericidal/permeability-increasing protein (BPI) [66]. For example, MPO is a powerful bactericidal protein that selectively binds to and quickly kills bacteria such as Escherichia coli, Pseudomonas aeruginosa, Staphylococcus aureus and Streptococcus pyogenes in the presence of Streptococcus pneumoniae [66]. BPI has shown independent antimicrobial activity against gram-negative bacteria, such as Escherichia coli, and can neutralize bacterial endotoxins. The antibacterial activity of these bactericidal proteins is helpful in regulating the symbiotic bacteria of the upper respiratory tract.

In addition, IL-33 can increase the expression of thymic stromal lymphopoietin (TLSP) in DC cells and then change the differentiation of $\mathrm{T}$ cells to favor $\mathrm{CD} 4^{+}$ $\mathrm{T}$ cells expressing Th2 characteristic cytokines [67]. It can also induce type II congenital lymphoid cells (ILC2 cells) the increased secretion of IL-4 and IL-13 levels, which further promote mucus secretion [68]. This IL-13-induced Th2 cellular immune response is thought to be closely related to chitinase 3-like 1 protein (CHI3L1); that is, CHI3L1 is proposed to enhance airway hyperreactivity (AHR), inflammatory cell recruitment and mucus production in RSV-infected hosts [69]. Finally, excessive mucus secretion and exfoliated airway cilia and airway epithelial cells caused by RSV infection together with neutrophils and lymphocytes in the airway lead to airway obstruction.

A growing body of evidence suggests that severe RSV disease is associated with an inadequate immune response and a low viral load. For example, when the researchers analyzed the upper respiratory viral load and immune response of infants hospitalized with acute bronchiolitis caused by RSV and other viruses, they found that infants with severe disease showed lower RSV viral load and lower concentrations of IFN- $\gamma$ and CCL5/RANTES compared with infants with moderate disease [70]. Heinonen et al. drew the same conclusion through transcription mapping and multiparameter flow cytometry combined with a systematic analysis of clinical data. In addition, the latter group found that, compared with severely hospitalized patients, children with mild disease had high expression of plasma cell and inflammatory genes, lower activation of neutrophil and monocyte gene expression, and reduced inhibition of $\mathrm{T}$ cell and NK cell gene expression [71]. IL-21/IL-21R bound together in the presence of other costimulatory signals drove the differentiation of memory cells, germinal center B cells or plasma cells to produce high-affinity antibodies to protect host cells from pathogens. RSV inhibited the humoral immune response of B cells by negatively regulating the expression of IL-21R on the surface of T follicular helper (TFH) cells and IL-21 in immature B cells. These findings may explain the lack of an immune response [72]. In infants with severe respiratory tract infection, the production of IFN- $\gamma$ by NK cells induced by specific antibodies to RSV was significantly lower than that in uninfected infants, and the activation of these NK cells seemed to be related to Fc fucosylation of RSV-specific antibodies [73].

Notably, during RSV infection, the severity of bronchiolitis and wheezing disease was related to other factors, such as respiratory bacteria. Nasal 
mucus samples obtained from children with mild and severe RSV diseases were analyzed by $16 \mathrm{~S}$ ribosomal sequencing to characterize the microbiota [74]. The results showed that all five major bacterial communities showed the characteristics of being the dominant bacteria types. RSV infection and hospitalization were positively correlated with an abundance of Haemophilus influenzae and Streptococcus and negatively correlated with an abundance of Staphylococcus aureus. Streptococcus pneumoniae (gram positive) and Haemophilus influenzae (gram negative) were also found to be the most common bacterial isolates in other studies of lower respiratory tract bacterial coinfections in hospitalized patients with RSV infection [75]. These results suggest that airways damaged by RSV infection may be more vulnerable to secondary bacterial infection. The expression of some bacterial receptors, such as intercellular adhesion molecule-1 (ICAM-1), platelet activating factorreceptor (PAF-r) and carcinoembryonic antigenassociated cellular adhesion molecule 1 (CEACAM1), was induced during RSV infection, which enhances the binding of bacteria to prolong lower respiratory tract infection (LRTI).

\section{Potential intervention strategies}

The preclinical and clinical development of RSV intervention can be roughly classified into three categories: monoclonal antibodies, vaccines and small molecules. Each of these strategies has its own unique advantages and disadvantages, but each solution is expected to be a candidate to pass clinical trials.

\section{Antibodies}

Antibodies are important prophylactic treatments for patients at risk of serious RSV infection. RSV virions contain F, G and SH surface proteins, among which the $\mathrm{F}$ protein is highly conserved among RSV strains and is the main target of protective neutralizing antibodies. The first treatment used to prevent RSV infection was RespiGam developed by Medimmune, which is a mixture of human intravenous immunoglobulin (IVIG) containing high concentrations of RSV protective antibodies. It is effective in the prevention of severe LRTI caused by RSV infection in high-risk infants. With the introduction of palivizumab (Synagis), Medimmune voluntarily stopped using RespiGam in 2003. Palivizumab is a humanized mouse $\mathrm{mAb}$ that can bind to the RSV F protein. It was also the first antiviral $\mathrm{mAb}$ approved for human treatment. Palivizumab can effectively prevent RSV hospitalization for high-risk premature infants with pregnancy less than 32 weeks in the first 6 months after discharge [76]. However, due to its limited cost and effectiveness, which are similar to those of RespiGam, it is currently approved only for the prevention of RSV in premature infants and infants with cardiopulmonary diseases at birth. Motavizumab (MEDI-524) is a second-generation palivizumab product. It mutates 13 specific amino acid residues located in the variable region of the CDR sequence of the antibody, thus enhancing its affinity and neutralization by $70-$ and 100-fold, respectively [77]. The results from a phase 3 clinical trial revealed that motavizumab showed better neutralization ability and a longer half-life than palivizumab, which makes it a promising candidate. MEDI-557, a next-generation product of motavizumab in which three amino acids are substituted in the Fc region (M252Y/S254T/T256E (YTE)), increased the binding to FcR by 10 -fold and increased the serum half-life by 4 -fold [78]. Two phase I clinical trials on the safety, tolerance and pharmacokinetics of motavizumab have been completed (NCT00578682 and NCT01562938). A clinical trial with healthy adults with nasal RSV infection was suspended due to an unmet schedule and budget (NCT01475305).

Over the past decade, because of the great advances in $\mathrm{mAb}$ screening technology, hundreds of human antibodies against RSV F proteins have been isolated and identified. Among these antibodies, many RSV F-specific antibodies have been shown to be much more effective than palivizumab. Kwakkenbos et al. transformed peripheral blood memory cells (PBMCs) into germinal center-like B cells that express specific antibodies to RSV by introducing Bcelllymphoma-6 (Bcl-6) and Bcl-xL genes [79]. The $50 \%$ inhibitory concentration (IC50) of the screened D25 mAb against respiratory syncytial virus A2 virus was $2.1 \mathrm{ng} / \mathrm{ml}$, which was 100 -fold higher than that of palivizumab, and the D25 mAb led to significantly reduced function and potency of RSV replication in a cotton rat model. After YTE substitution of three amino acids in the highly conserved Fc region of D25, the nirsevimab (MEDI8897) antibody was generated. The YTE substitution enhanced the binding of IgG1 to the neonatal Fc receptor (FcRN) and improved its anti-degradation performance, thus prolonging the half-life of the antibody in serum (the average half-life ranged from 85 to 117 days) [80]. In a phase $1 \mathrm{~b} / 2 \mathrm{a}$ dose-ranging study $(10,25$, and $50 \mathrm{mg}$ of nirsevimab or placebo) with healthy premature infants aged 32-35 weeks, $90 \%$ of the inoculated infants exhibited a fourfold increase in serum RSV-neutralizing antibody levels compared with the control group, and the half-life of the antibody supported continuous protection for 5 months [81]. The results also showed 
that nirsevimab significantly reduced the consultation rate and hospitalization rate for RSV infection by $70.1 \%$ and $78.4 \%$, respectively, compared with the placebo (saline) control group [82]. Currently, a clinical trial on the safety of preventing RSV LRTI in high-risk children is being evaluated (NCT03959488).

Suptavumab (REGN-2222) is a human monoclonal IgG1 antibody specific to the RSV pre-F protein. It is significantly more potent in neutralizing RSV than palivizumab and has good tolerance and a longer half-life in healthy adults [83]. However, a phase 3 trial of 1154 premature infants showed that all RSV subtype B isolates had two amino acid mutations in the epitopes, resulting in the loss of suptavumab neutralizing activity, which led to the discontinuation of its clinical development [84]. Tang et al. screened the potent RSV mAb RB1 from human memory B cells [85]. This antibody could bind to a highly conserved epitope on antigenic site IV of the F protein in both RSV subtype A and B. RB1 effectively neutralized a variety of clinical isolates of RSV in vitro approximately 100-fold more effectively than palivizumab, and it showed good protective effects in a cotton rat model. Its optimized antibody, MK-1654, is currently being tested in a phase $2 b / 3$ clinical study to evaluate its efficacy and safety in healthy premature and full-term infants (NCT04767373).

In addition, some other pre-F-specific antibodies are also in the preclinical development stage. For example, Orti et al. screened a broad-spectrum HRSVand HMPV-neutralizing antibody MPE8 from the peripheral blood of a donor infected with HRSV and then infected with HMPV by flow cytometry. MPE8 showed great potential not only in preventing HRSV and HMPV infections in newborns but also in immunocompromised adults [86]. ALX-0171 is a trivalent RSV-neutralizing nanobody that binds to a palivizumab-like epitope on RSV F. It consists of three univalent $\mathrm{Nb017}$ molecules connected by a glycineserine (GS) linker [87]. In a phase $1 / 2$ a clinical trial, ALX-0171 inhaled daily for three days by 175 hospitalized RSV-infected children between 28 days and 24 months old was shown to be safe, as no serious treatment-related adverse events were found (NCT02309320). However, upon RSV infection develops in the lower respiratory tract, inhaling RSV therapeutic antibodies through the nose may not improve the clinical course of the disease [88]. Using phage display library technology, Rossey et al. screened two candidate camelid single-domain antibodies (VHH), F-VHH-4 and F-VHH-L66, which have strong RSV-neutralizing activity (IC50 < 0.1 $\mathrm{nM}$ ) [89]. The results indicated that these antibodies performed similar to or better than F-specific mAbs D25 and AM22. F-VHH-4 and F-VHH-L66 inhibited RSV infection by blocking membrane fusion between the virus and the target Hep-2 cells in vitro. In addition, these VHHs also prevented RSV replication and lung infiltration caused by inflammatory monocytes and $\mathrm{T}$ cells in RSV-infected mice [89]. These pre-F-specific VHHs represent promising anti-RSV drugs. Recently, Tiwari et al. presented a strategy of directly expressing neutralizing antibodies via mRNA in the lungs [90]. When mRNA expressing palivizumab was delivered in the form of aerosols to the lungs of mice, the copy number of RSV F was reduced by approximately $90 \%$. Moreover, RSV replication was significantly inhibited 7 days after an anchored VHH-expressing mRNA was transfected into the lungs of mice, and the antibody level persisted for at least 28 days. This method of expressing membrane-anchored broadly neutralizing antibodies in the lungs may be promising for preventing lung infection.

Although RSV G (298 amino acid residues) generally has highly variable and heterogeneous $\mathrm{N}$ and O-glycosylated mucin-like regions, it also contains a CCR of $\sim 40$ amino acids. The CCR is not glycosylated but contains a CX3C chemokine motif; this motif can promote binding to the human chemokine receptor CX3CR1, which is a key step in RSV infection in human respiratory epithelial cells [91]. Antibodies against the $G$ protein are also in preclinical development, and these antibodies have been shown to inhibit virus attachment. Collarini et al. used a phenotypic cell-sorting technique to screen the high-affinity antibody 3G3, which could specifically bind to the CCR of the RSV G protein [92]. This antibody showed good virus clearance activity in a mice model for infection prevention and treatment and is expected to be an attractive candidate for the clinical treatment of RSV. Anderson et al. obtained the $\mathrm{mAb} 131-2 \mathrm{G}$ against the RSV G protein using the hybridoma technique. The virus titer in the lungs of mice injected intraperitoneally with $300 \mu \mathrm{g}$ of the antibody decreased by $99 \%$ [93]. Lee et al. used the same method to screen two mAbs, 5H6 and 3A5. Intravenous injection of $100-200 \mu \mathrm{g}$ of mAbs protected mice from RSV infection and promoted the clearance of the virus from the lungs [94]. These antibodies may be used as alternatives to prevent RSV infection. However, the $\mathrm{N}$-terminus and $\mathrm{C}$-terminus of the extracellular domain of the $G$ protein also contain multiple antibody-binding protected sites [95]. Table 1 lists select potential RSV-neutralizing antibodies and related information. 
Table 1. Selected antibodies for the prevention of RSV infection

\begin{tabular}{|c|c|c|c|}
\hline Prototypic antibodies & Target site & Method of generation & Reference \\
\hline D25, MEDI8897 (Nirsevimab) & Antigen site $\varnothing$ of the RSV pre-F protein & B cell culture & {$[80,96]$} \\
\hline $\begin{array}{l}\text { Palivizumab, motavizumab, } \\
\text { MEDI-557 }\end{array}$ & Antigenic site II of the RSV F protein & Hybridoma technology & {$[76,77]$} \\
\hline Suptavumab (REGN-2222) & Antigenic site $\mathrm{V}$ of the RSV pre-F protein & VelocImmune technology & {$[83,84]$} \\
\hline RB1, MK-1654 & Antigenic site IV of the RSV pre-F protein & B cell culture & [85] \\
\hline MPE8 & Antigenic site III of the RSV pre-F protein & Single B cell cloning & [86] \\
\hline ALX-0171 & Antigenic site II of the RSV pre-F protein & Immune libraries of llamas & [87] \\
\hline F-VHH-4, F-VHH-L66 & $\begin{array}{l}\text { The cavity in the intermediate region between antigenic site II and } \\
\text { IV of the RSV F protein }\end{array}$ & Phage display libraries & [89] \\
\hline $3 \mathrm{G} 3$ & CCR of the RSV G protein & B cell immunization & [92] \\
\hline $131-2 \mathrm{G}$ & CCR of the RSV G protein & Hybridoma technology & [93] \\
\hline $5 \mathrm{H} 6$ and $3 \mathrm{~A} 5$ & CCR of the RSV G protein & Hybridoma technology & [94] \\
\hline
\end{tabular}

Table 2. Selected RSV vaccines under clinical development

\begin{tabular}{|c|c|c|c|c|}
\hline $\begin{array}{l}\text { Types of } \\
\text { vaccine }\end{array}$ & Vaccine name & Description & $\begin{array}{l}\text { Clinical } \\
\text { status }\end{array}$ & Clinical trial number \\
\hline \multirow{7}{*}{$\begin{array}{l}\text { Live } \\
\text { attenuated } \\
\text { vaccine }\end{array}$} & RSV MEDI $\triangle \mathrm{M} 2-2$ & A M2-2 gene-deleted live attenuated vaccine & Phase 1 & NCT01459198 \\
\hline & RSV LID $\Delta \mathrm{M} 2-2$ & A M2-2 gene-deleted live attenuated vaccine & Phase 1 & $\begin{array}{l}\text { NCT02952339; NCT02601612; } \\
\text { NCT02237209 }\end{array}$ \\
\hline & $\mathrm{LID} / \Delta \mathrm{M} 2-2 / 1030 \mathrm{~s}$ & An optimized M2-2 gene-deleted live attenuated vaccine & Phase 1 & NCT02794870 \\
\hline & RSV $\Delta$ NS2 $\Delta 1313$ I1314L & An optimized NS2 gene-deleted live attenuated vaccine & Phase $1 / 2$ & NCT03227029; NCT03422237 \\
\hline & RSV $6120 / \Delta N S 2 / 1030 s$ & An optimized NS2 gene-deleted live attenuated vaccine & Phase $1 / 2$ & NCT03387137 \\
\hline & RSV $6120 / \Delta N S 1$ & An optimized NS1 gene-deleted live attenuated vaccine & Phase 1 & NCT03596801 \\
\hline & $\mathrm{D} 46 / \mathrm{ns} 2 / \mathrm{N} / \Delta \mathrm{M} 2-2-H i n d I I I$ & An optimized M2-2 gene-deleted live attenuated vaccine & Phase 1 & NCT03099291; NCT03102034 \\
\hline \multirow{4}{*}{$\begin{array}{l}\text { Protein/ } \\
\text { subunit } \\
\text { vaccine }\end{array}$} & VRC-RSVRGP084-00-VP & $\begin{array}{l}\text { An F protein vaccine developed on the basis of the trimer pre-F } \\
\text { protein DS-Cav1 }\end{array}$ & Phase 1 & NCT03049488 \\
\hline & $\begin{array}{l}\text { GSK3844766A and } \\
\text { GSK3888550A }\end{array}$ & $\begin{array}{l}\text { An F protein vaccine developed on the basis of the F/pre-F } \\
\text { protein }\end{array}$ & Phase $1 / 2$ & $\begin{array}{l}\text { NCT04126213; NCT04138056; } \\
\text { NCT04090658 }\end{array}$ \\
\hline & DepoVax (DPX)-RSV & $\begin{array}{l}\text { An SH protein vaccine developed on the basis of lipid agent } \\
\text { DepoVax }\end{array}$ & Phase 1 & NCT02472548 \\
\hline & BARS13 & A G protein vaccine & Phase 1 & ACTRN12618000948291 \\
\hline \multirow{4}{*}{$\begin{array}{l}\text { Vector-based } \\
\text { vaccine }\end{array}$} & Ad26.RSV.preF & Ad26 vector-encoding gene of the pre-F protein & Phase $2 b$ & NCT03982199 \\
\hline & SeVRSV & $\mathrm{SeV}$ vector-encoding gene of the full-length F protein & Phase 1 & NCT03473002 \\
\hline & GSK3389245A (ChAd155-RSV) & ChAd155 vector-encoding gene of the $\mathrm{F}, \mathrm{N}$ and $\mathrm{M} 2-1$ proteins & Phase $1 / 2$ & NCT03636906; NCT02927873 \\
\hline & MVA-BN RSV & MVA-BN vector-encoding gene of the $F, G, N$ and $M 2$ proteins & Phase 2 & EUCTR2017-004582-27-BE \\
\hline $\begin{array}{l}\text { mRNA-based } \\
\text { vaccine }\end{array}$ & mRNA-1345 & Encoding a prefusion F glycoprotein & Phase 1 & NCT04528719 \\
\hline
\end{tabular}

\section{Vaccine}

An effective vaccine to protect high-risk groups from severe RSV infection will be indispensable. In the 1960s, clinical trials of a formalin-inactivated RSV vaccine for infants aggravated RSV disease and eventually led to the death of two infants. This unacceptable situation may have been related to immune complex accumulation in the bronchioles induced by the vaccine with weak neutralizing activity but a high complement binding titer and the Th2-based $\mathrm{CD}^{+} \mathrm{T}$ cell response in the cellular immune response $[97,98]$. Currently, dozens of promising vaccines are being developed to prevent RSV infection, and they are mainly attenuated vaccines, subunit vaccines and vector-based vaccines. The most fundamental principle of RSV vaccine design, regardless of type, always follows the principle that RSV-neutralizing antibodies need to be introduced into airway mucosa in the most reasonable way possible [99]. Table 2 lists some representative vaccines and related information.

\section{Live attenuated vaccines}

One of the basic goals of live attenuated vaccines is to limit the replication of RSV in recipients through traditional measures (such as heating or chemical treatment) or reverse genetic techniques to maintain an appropriate and natural balance of $\mathrm{B}$ and $\mathrm{T}$ cell responses, thereby avoiding vaccine-enhanced diseases. Currently, there are approximately 30 active clinical trials of live attenuated RSV vaccines registered at ClinicalTrials.gov.

Most of these vaccines are attenuated by deletion of genes such as those generated by M2, NS2/NS1 and $\mathrm{L}$ mutations. As mentioned above, deletions of RSV M2-2 or NS2/NS1 protein sequences have been shown to hinder or interfere with viral RNA 
replication. For example, both RSV MEDI $\triangle \mathrm{M} 2-2$ and LID $\Delta \mathrm{M} 2-2$ vaccines can induce a strong neutralizing antibody response to RSV [100,101]. Some optimized versions carry two site mutations on the $\mathrm{L}$ gene, such as LID $\Delta \mathrm{M} 2-2 / 1030 \mathrm{~s}$, which achieved a better attenuated effect and higher RSV-neutralizing antibody titer than a maternal vaccine [102]. Vaccines based on NS2/NS1 deletion, such as RSV $\triangle$ NS2 $\Delta 1313$ I1314L, RSV 6120/ $\Delta$ NS2/1030s, and RSV 6120/ $\Delta$ NS1, are under clinical evaluation (NCT01893554, NCT03916185 and NCT03387137). Recently, the vaccine D46/NS2/N/ $\Delta$ M2-2-HindIII has been shown to have greater attenuated toxicity and a higher neutralizing antibody titer than the maternal vaccine LID $\Delta$ M2-2 (NCT03102034 and NCT03099291) [103]. In addition, Meissa Vaccines produced the highly attenuated vaccine MV-012-968 by optimizing the codons of the NS2, NS1 and G genes, as well as by deleting the $\mathrm{SH}$ gene, which had been proven to have a strong protective effect in a cotton rat model. A phase 2 clinical trial for determining the efficacy of this vaccine in humans are currently being evaluated (NCT04227210). Recently, Jenkins et al. designed and produced the live attenuated RSV vaccine candidate rgRSV-L(G1857A)-G(L208A) [104] by introducing two modifications: one attenuating mutation in the $\mathrm{L}$ protein and another mutation in the G glycoprotein. The former mutation did not inhibit virus production in Vero cell culture but greatly reduced the transmission of the virus in human bronchial epithelium, and the latter mutation reduced the cleavage of the vaccine virus in Vero cells, thus increasing the yield and making the production more economical. In cotton rat treated with this candidate vaccine, RSV replication was undetectable even at a dose of $10^{5}$ plaque-forming units (PFU), and it was sufficient to completely protect against RSV A2 infection after 500 PFUs immunization [104]. This may be a potential candidate for a live attenuated RSV vaccine.

\section{Protein/subunit vaccines}

Currently, the protein/subunit vaccines evaluated in clinical trials are mainly focused on the F protein. For these vaccines, the focus is primarily on the epitopes that can induce a B cell response to produce strong neutralizing activity for generating vaccines with long-term protective effects. This kind of vaccine can minimize the production of non-neutralizing or weakly neutralizing antibodies in the process of immunization, thus weakening antibody-dependent enhancement (ADE) [105]. RSV F DS-CaV1 is an F protein vaccine developed by NIAID based on the pre-F trimer DS-Cav1 with a stable conformation. In a phase 1 clinical trial, the evaluation of the safety and immunogenicity of DS-Cav1 in healthy adults aged 18-50 years showed that it was safe and induced strong RSV F-specific antibodies and neutralizing activity lasting more than 44 weeks (NCT03049488) [106]. GlaxoSmithKline has produced two F-based vaccines, GSK3844766A and GSK3888550A, that have been subjected to phase 2 clinical evaluations for safety and immune response in the elderly and pregnant women, respectively. Both of these vaccines stimulated a strong immune response and were well tolerated [107]. Currently, the company is preparing for the implementation of phase 3 clinical trials. Novartis RSV F protein nanoparticle, which is mainly based on the postfusion F conformation, shows antigenicity site II binding. It failed to protect newborns of vaccinated pregnant women in its phase 3 clinical trial [108]. One of reason contributing to this clinical result may be due to the fact that the postfusion conformation cannot elicit a wider range of neutralizing antibodies as the prefusion conformation [109].

Phase 1 clinical trials have been completed on subunit vaccines, which are based on other proteins including DepoVax (DPX)-RSV and BARS13. DepoVax (DPX)-RSV, developed by Dalhousie University, is a candidate protein vaccine directed toward the extracellular domain of $\mathrm{SH}$ protein containing the lipid-based DepoVax agent. In a phase 1 clinical study with healthy adults aged 50-64 years, DPX-RSV showed good safety and a specific antibody response that lasted for more than one-half year (NCT02472548) [110]. BARS13 is a protein vaccine developed by Advanced Vaccine Laboratories based on $G$ protein, and a phase 1 clinical evaluation of its safety and efficacy in the elderly is being carried out (NCT04681833).

In addition, some promising studies have also provided a new path for the research and development of protein/subunit vaccines. Herv é et al. prepared a skin surface RSV vaccine using a Viaskin ${ }^{\circledR}$ skin patch as the delivery platform and RSV $\mathrm{N}$-nanorings $(\mathrm{N})$ as subunit antigens [111]. This needle-free vaccine may be better received by sensitive groups such as babies because it does not require skin preparation. In mice and pigs, it showed a high level of immunogenicity to promote a Th1/Th17-oriented immune response and provided strong protection against viral replication during RSV infection without aggravating clinical symptoms. A chimeric vaccine candidate, rBCG-N-HRSV, consisting of bacille Calmette-Guérin (BCG)expressing RSV N, has been shown to have protective effects in mice. A single-dose vaccine can protect mice from pathogenic infection with $1 \times 10^{7}$ PFUs of the RSV A2 clinical virus strain. A phase 1 clinical trial is 
currently under evaluation (NCT03213405) [112]. In addition, Marcandalli et al. designed DS-Cav1 protein nanoparticles based on structural self-assembly [113]. The nanoparticle scaffold I53-50 consists of 20 trimers and 12 pentamers for a total of 120 subunits. The two-component feature of this scaffold enables it to produce highly ordered, monodisperse immunogens. A stable pre-F DS-Cav1 trimer protein was presented on the outside of the nanoparticle substrate in the form of repeated arrays. When mice and nonhuman primates were inoculated, the immunogenicity of nanoparticles containing 20 DS-Cav1 trimers was 10-fold greater than that of the trimer DS-Cav1 alone [113]. Most recently, Swanson et al. fused the RSV pre-F protein into self-assembled ferritin nanoparticles, which were modified with glycans to cover non-neutralizing or poorly neutralizing epitopes [114]. Each of the optimized pre-F-NP contain 8 pre-F proteins. Pre-F-NP induced persistent pre-F-specific antibodies and produced effective neutralizing antibody responses in mouse and nonhuman primate models. Compared with the pre-F trimer DS-Cav1, pre-F-NP stimulated a stronger antibody response. These results encourage the continued development of these promising nano RSV vaccines.

\section{Vector-based vaccines}

Vector-based vaccines transmit RSV antigens through vectors and induce specific immune responses. To date, eight vector-based vaccines for RSV infection have been tested in clinical trials, of which 4 (including MEDI-534, VXA-RSV-f oral, RSV001, Ad26.RSV.FA2) were ineffective or no longer under development. Ad26.RSV.Pre-F, developed by Janssen, is a vector-based vaccine based on human adenovirus 26 strain (Ad26) expressing stable pre-F protein [115]. In a cotton rat model, the vaccine could induce the production of $\mathrm{CD}^{+} \mathrm{T}$ cells expressing IFN- $\gamma$ and TNF- $\alpha$ markers of the Th1 immune response and showed minimal damage or inflammatory infiltration in the lungs after RSV challenge. Moreover, the high titer of RSV-neutralizing antibody produced after immunization could last for more than 30 weeks and produced protective immunity to RSV virus in the lung and nasal cavity. A phase $2 \mathrm{a}$ clinical trial conducted with 180 elderly patients older than 60 years of age showed that Ad26.RSV.preF had an acceptable safety profile with no observed interference of immune responses [116]. Currently, the safety, responsiveness and immunogenicity of this vaccine in RSV-negative children aged 12-24 months are being evaluated in a phase $1 / 2$ clinical trial (NCT03606512). Another clinical study evaluating the safety and immunogenicity of Ad26.RSV.preF in adults older than 60 years have not reported the results (NCT03502707). SeVRSV is a vaccine based on $\mathrm{SeV}$, a mouse parainfluenza virus type 1 (PIV1), which encodes the full-length gene of RSV F [117]. The safety and responsiveness of intranasal injection of the SeVRSV vaccine were evaluated in healthy adults aged 18-45 years in a phase 1 clinical trial. The study showed that the vaccine was well tolerated [118]. ChAd155-RSV is an RSV vaccine developed by GlaxoSmithKline based on the design of chimpanzee adenovirus-155 (ChAd155) [119]. In contrast to the previous two vector-based vaccines, this vector contains genes that encode three proteins (F, N and M2-1) of RSV. In a phase 1 clinical trial of 72 healthy adults aged 18-45 years, ChAd155-RSV was not found to cause significant safety issues, and its specific humoral and cellular immune responses were high [119]. Currently, the results of two clinical trials with infants (a phase 2 study with infants aged 12 to 23 months (NCT02927873) and the phase 1 study with infants aged 6 and 7 months (NCT03636906)) have not yet been published. MVA-BN-RSV is a multivalent vector vaccine. The MVA-BN-based vector developed by Bavarian Nordic is a genetically engineered virus derived from the modified Ankara vaccinia virus (MVA)) that has lost the ability to replicate in human cell lines but can effectively infect mammalian cells [120], and it carries F, G, M2 and N genes encoding RSV structural proteins. The results of a phase 2 clinical evaluation of the dose and vaccination regimen of MVA-BN-RSV in adults older than 55 years showed that MVA-BN-RSV was safe and that a single dose could induce a cellular immune response biased towards Th1 cells and an antibody response that lasted for more than one-half year [121]. Currently, a phase 3 clinical trial is being planned.

\section{mRNA-based vaccines}

This strategy may not only eliminate the need for the purification of protein/subunit vaccines by fermentation, which is particularly challenging for antigens that are difficult to purify or that show poor stability, but may also prevent the anti-vector immune reaction encountered upon administration of vector-based vaccines. An mRNA vaccine can also induce strong humoral and cellular immune responses at the same time. In fact, data have shown that transcribed mRNA encapsulated in lipid nanoparticles (mRNA/LNP) is potentially safe and effective in vitro for preventing RSV diseases [122]. mRNA-1345 is developed by Moderna encoding a prefusion F glycoprotein, which is conducting a phase I clinical study to assess the tolerance and responsiveness of young people, women of childbearing age, the elderly and seropositive 
children. The phase I mid-term results showed that there were no adverse events at a dose of $100 \mu \mathrm{g}$, and this vaccine produced RSV-neutralizing antibodies at a rate of more than 21-fold, compared with that of the control group, in the first month [123].

\section{Inhibitors}

Ribavirin, a nucleoside analog, is the only clinically approved antiviral inhibitor for the treatment of RSV infection. However, the drug is restricted for the treatment of children because of concerns about teratogenicity and occupational exposure [124]. At present, the development of small-molecule inhibitors of RSV infection is mainly based on two modes of action: in one mode, the invading virions are blocked from binding to the $\mathrm{F}$ protein on the surface of RSV, and in the other mode, the production of new virions is inhibited by blocking viral transcription and replication. Table 3 summarizes some representative inhibitors currently being developed for RSV infection and related clinical information.

GS-5806 (presatovir) is an RSV F inhibitor developed by Gilead Sciences. It can effectively prevent RSV F-mediated intercellular fusion, showing an average $50 \%$ effective concentration (EC50) of 0.43 $\mathrm{nM}$ for 75 different clinically isolated RSV A and B virus strains in vitro and low cytotoxicity in human cell lines and primary cell cultures [125]. In a challenge study of intranasal RSV infection in healthy adults, participants treated with GS-5806 had a lower viral load and lower neutrophil count and total mucus weight than those in the control group, reducing the severity of clinical disease [126]. A phase $2 b$ clinical trial has been completed to evaluate the antiviral effect of GS-5806 on adult hospitalized patients with RSV infection, but no results have been published to date (NCT02135614). Another phase 2b study performed to evaluate the efficacy of presatovir in RSV LRTI in patients with hematopoietic cell transplants (HCTs) did not improve virological or clinical outcomes despite it being well tolerated [127]. JNJ-53718678 (JNJ-678) is another effective RSV F protein inhibitor developed by Johnson Company. Similar to GS-5806, it blocks the invasion of virus particles by combining with pre-F with high affinity (Kd value of $7.4 \mathrm{nM}$ ). It showed strong anti-RSVA2 activity in vitro, and the EC50 value was 480 pM [128]. Roymans et al. found that JNJ-53718678 could bind to the $\mathrm{F}$ protein with strong nanoaffinity activity. Oral treatment of newborn lambs with JNJ-53718678 effectively inhibited identifiable acute lower respiratory infections, even when treatment was delayed until external symptoms of RSV disease became apparent [129]. A recent phase 2 clinical study of healthy adults showed that JNJ-53718678 treatment significantly reduced viral load and clinical disease severity (NCT02387606). RO-0529 and RV521, developed by Ark Biosciences and ReViral, respectively, have shown good anti-RSV clinical isolate activity in vitro and in vivo. Currently, RO-0529 is in phase $2 / 3$ clinical trials for the evaluation of its efficacy in hospitalized adult and infant patients (NCT03699202 and NCT04231968). The phase 2a clinical results of RV521 showed that both $350 \mathrm{mg}$ and $200 \mathrm{mg}$ of the inhibitor could significantly reduce viral load and disease severity 5 days after RSV infection (NCT03258502) [128].

Table 3. Selected RSV vaccines under clinical development

\begin{tabular}{|c|c|c|c|c|}
\hline Inhibitors & Target & Mechanism of action & Clinical status & Clinical trials \\
\hline GS-5806 (Presatovir) & F protein & Targets the RSV F protein to inhibit the entry of the virus & Phase $2 \mathrm{~b}$ & $\begin{array}{l}\text { NCT02254421; EudraCT, } \\
\text { \#2014-002475-29 }\end{array}$ \\
\hline JNJ-53718678 & & Targets the RSV F protein to inhibit the entry of the virus & Phase $1 b / 2$ & $\begin{array}{l}\text { NCT02593851; NCT03656510; } \\
\text { NCT04056611 }\end{array}$ \\
\hline $\begin{array}{l}\text { AK0529 (Ziresovir, } \\
\text { RO-0529) }\end{array}$ & & Targets the RSV F protein to inhibit the entry of the virus & Phase $2 / 3$ & NCT03699202; NCT04231968 \\
\hline RV521 & & Targets the RSV F protein to inhibit the entry of the virus & Phase $2 \mathrm{a}$ & NCT03258502 \\
\hline RSV604 & $\mathrm{N}$ protein & $\begin{array}{l}\text { Inhibits the interaction between the virus and host proteins that } \\
\text { facilitate RSV } 604 \text { binding of the N protein to block effective viral } \\
\text { transcription. }\end{array}$ & Phase 1 & NCT00416442 \\
\hline EDP-938 & & $\begin{array}{l}\text { Targets binding of viral N protein to block RSV replication in the } \\
\text { postreplication phase }\end{array}$ & Phase 2 & NCT04816721 \\
\hline ALN-RSV01 & RNA & $\begin{array}{l}\text { Targets RSV N transcripts by forming an RNA-induced silencing } \\
\text { complex to inhibit translation }\end{array}$ & Phase $2 b$ & NCT01065935; NCT00658086 \\
\hline lumicitabine (ALS-8176) & Polymerase L & $\begin{array}{l}\text { Targets RSV polymerase complex, causing chain termination of RNA } \\
\text { synthesis }\end{array}$ & Phase $2 a$ & NCT02673476 \\
\hline AZ-27 & & Inhibits the initiation of RNA synthesis from the promoter & Preclinical & Null \\
\hline PC786 & & Interrupts RSV L-protein polymerase activity & Phase $1 / 2$ & NCT03382431 \\
\hline JNJ-64417184 & & Interrupts RSV L-protein polymerase activity & Phase 1 & NCT04121052; NCT04258189 \\
\hline
\end{tabular}

Sources: ClinicalTrials.gov and clinicaltrialsregister.eu. 
Another potentially interesting target is the $\mathrm{N}$ protein, which is an important component of the polymerase complex and the most conserved viral protein that plays an indispensable role in RNA transcription and replication. RSV604, an analog of 1,4-benzodiazepine, has been found to hinder optimal viral transcription by directly binding to RSV N [130]. Some promising antiviral activities were shown in early clinical studies, but the studies were stopped because of its poor efficacy. Then, EDP-938 was identified after re-optimization of 1,4-benzodiazepine. The results showed that it inhibited RSV by blocking RSV $\mathrm{N}$ to prevent the virus from entering the postreplication stage of its life cycle. EDP-938 showed high antiviral activity against all RSV laboratory and clinical isolates in vitro, and its EC50 value was 21 64 $\mathrm{nM}$ [131]. Currently, EDP-938 is being evaluated in a phase 2 clinical study (NCT04816721). ALN-RSV01, a small interfering RNA (siRNA), forms an RNA-induced silencing complex by targeting the mRNA of RSV N to inhibit translation and ultimately reduce viral load. In a phase 2 clinical study of 88 healthy adults, ALN-RSV01 significantly reduced the viral activity of participants with RSV infection [132]. In another phase $2 b$ clinical trial conducted with RSV-infected lung transplant patients, although ALN-RSV01 showed good tolerance and reduced the risk of bronchiolitis obliterans syndrome after RSV infection, there was no significant difference in viral parameters or symptom scores between the treatment group and the control group [133].

In addition, the large polymerase protein $\mathrm{L}$ of RSV is necessary for viral mRNA transcription and genome replication. The development of inhibitors for RSV L is also an attractive target for antiviral intervention. Currently, some potential inhibitors, such as lumicitabine (ALS-8176), AZ-27, PC786 and JNJ-64417184, are being evaluated in clinical trials. TMEM16A is a major secretory anion channel in airway epithelial cells that is upregulated during airway inflammation and asthma. Recently, Pearson et al. found that TMEM16A inhibitors showed the potential for preventing RSV infection [134]. Thus, the effectiveness of TMEM16A inhibitors as anti-RSV drugs needs to be tested in vivo as they may provide new ways to develop RSV inhibitors. Most recently, Risso-Ballester et al. reported that A3E, a steroidal alkaloid cyclopamine analogue, can inhibit RSV replication by targeting RSV transcription factor M2-1 to dissociate and harden IB, and in vivo experiments demonstrated that A3E can significantly inhibit RSV infection in the lungs of mice [135].

\section{Conclusions and future perspectives}

It has been more than 60 years since RSV was discovered, and RSV has become one of the most important pathogens causing respiratory diseases in the world. With continuous exploration, the roles of the various components of RSV are being explored in-depth, and the mysterious veil surrounding the mechanism by which RSV invades the host and its stepwise interaction with the host is being lifted. In the past decade, researchers have identified several key host cell receptors. In particular, the recent discovery of IGF1R, the main receptor of RSV infection in host cells, will undoubtedly stimulate many research ideas. Future experiments should be directed to determining how the $\mathrm{F}$ protein interacts with IGF1R at the atomic level. The elucidation of the structure of the F protein before and after fusion will undoubtedly play a guiding role in antibody development and vaccine design. Further study on the molecular structure that triggers the fusion of the $\mathrm{F}$ protein with the host membrane may stimulate new targets for the design of antibodies and smallmolecule inhibitors. A clearer understanding of the molecular immune response of host cells in the process of RSV infection will also contribute to the design of new drugs targeting potential regulatory molecules in the host immune pathway, such as IFN- $\gamma$, IL-33, etc. Although no antibodies, vaccines or inhibitors have been approved, with the exception of palivizumab, there are approximately 30 clinical interventions being evaluated and a large number of preclinical candidates. In the next five to ten years, the clinical prevention and treatment of RSV infection can be highly anticipated. However, similar to other RNA viruses, surface glycoproteins are the prone to mutation. Therefore, for the development of antibodies and small-molecule inhibitors, the global mutations and distribution of RSV must be identified and monitored because they may affect the results of clinical trials and even the efficacy of future products. Therapy consisting of a cocktail of two or more antibodies or small-molecule inhibitors should also be considered because this type of synergistic approach may reduce viral escape from host immunity. Although combination therapy has been proven to be a key strategy for achieving synergy and preventing the development of drug resistance by other viruses, whether this strategy will be effective in RSV treatment remains to be determined. In addition, the timing of starting treatment may also be critical. For example, if anti-RSV treatment is used early in the course of infection, it is more likely to show clinical benefits. For vaccines, more clinical research on mRNA vaccine of RSV should be carried out. Current research and clinical progress data on the prevention of RSV infection are optimistic, and we believe that more than one effective program will be approved 
and marketed in the near future to improve our ability to control RSV infection.

\section{Acknowledgements}

This work was financially supported by the Natural Science Basic Research Plan in Shaanxi Province of China (2020JQ-148) and Shenzhen Pathogen High-Throughput Sequencing Technical Engineering Laboratory Upgrading Project (2019-986).

\section{Author Contributions}

Zifang Shang completed the literature collection, the article writing, and the drawing of all the pictures and tables. Shuguang Tan provided the proofreading of the article, and Dongli Ma provided guidance and suggestions for the article writing.

\section{Competing Interests}

The authors have declared that no competing interest exists.

\section{References}

1. Morris JA, Blount RE and Savage RE. Recovery of Cytopathogenic Agent from Chimpanzees with Goryza. Proc. Soc. Exp. Biol. Med. 1956; 92(3):544-549.

2. Chanock R, Roizman B and Myers R. Recovery from infants with respiratory illness of a virus related to chimpanzee coryza agent (CCA). I. Isolation, properties and characterization. Am J Hyg. 1957; 66(3):281-290.

3. Glezen WP, Taber LH, Frank AL and Kasel JA. Risk of primary infection and reinfection with respiratory syncytial virus. Am J Dis Child. 1986; 140(6):543-546.

4. Shi T, McAllister DA, O'Brien KL, Simoes EAF, Madhi SA, Gessner BD, Polack FP, Balsells E, Acacio S, Aguayo C, Alassani I, Ali A, Antonio M, Awasthi S, Awori JO, Azziz-Baumgartner E, Baggett HC, Baillie VL, Balmaseda A, Barahona A, Basnet S, Bassat Q, Basualdo W, Bigogo G, Bont L, Breiman RF, Brooks WA, Broor S, Bruce N, Bruden D, Buchy P, Campbell S, Carosone-Link P, Chadha M, Chipeta J, Chou M, Clara W, Cohen C, de Cuellar E, Dang DA, Dash-Yandag B, Deloria-Knoll M, Dherani M, Eap T, Ebruke BE, Echavarria M, de Freitas Lázaro Emediato CC, Fasce RA, Feikin DR, Feng L, Gentile A, Gordon A, Goswami D, Goyet S, Groome M, Halasa N, Hirve S, Homaira N, Howie SRC, Jara J, Jroundi I, Kartasasmita CB, Khuri-Bulos N, Kotloff KL, Krishnan A, Libster R, Lopez O, Lucero MG, Lucion F, Lupisan SP, Marcone DN, McCracken JP, Mejia M, Moisi JC, Montgomery JM, Moore DP, Moraleda C, Moyes J, Munywoki P, Mutyara K, Nicol MP, Nokes DJ, Nymadawa P, da Costa Oliveira MT, Oshitani H, Pandey N, Paranhos-Baccalà G, Phillips LN, Picot VS, Rahman M, Rakoto-Andrianarivelo M, Rasmussen ZA, Rath BA, Robinson A, Romero C, Russomando G, Salimi V, Sawatwong P, Scheltema N, Schweiger B, Scott JAG, Seidenberg P, Shen K, Singleton R, Sotomayor V, Strand TA, Sutanto A, Sylla M, Tapia MD, Thamthitiwat S, Thomas ED, Tokarz R, Turner C, Venter M, Waicharoen S, Wang J, Watthanaworawit W, Yoshida LM, Yu H, Zar HJ, Campbell H and Nair H. Global, regional, and national disease burden estimates of acute lower respiratory infections due to respiratory syncytial virus in young children in 2015: a systematic review and modelling study. Lancet. 2017; 390(10098):946-958.

5. Ke Z, Dillard RS, Chirkova T, Leon F, Stobart CC, Hampton CM, Strauss JD, Rajan D, Rostad CA, Taylor JV, Yi H, Shah R, Jin M, Hartert TV, Peebles RS, Jr., Graham BS, Moore ML, Anderson LJ and Wright ER. The Morphology and Assembly of Respiratory Syncytial Virus Revealed by Cryo-Electron Tomography. Viruses. 2018; 10(8).

6. Linder KA and Malani PN. Respiratory Syncytial Virus. Jama. 2017; 317(1):98

7. Chatterjee S, Luthra P, Esaulova E, Agapov E, Yen BC, Borek DM, Edwards MR, Mittal A, Jordan DS, Ramanan P, Moore ML, Pappu RV, Holtzman MJ, Artyomov MN, Basler CF, Amarasinghe GK and Leung DW. Structural basis for human respiratory syncytial virus
NS1-mediated modulation of host responses. Nat Microbiol. 2017; 2:17101.

8. Pei J, Wagner ND, Zou AJ, Chatterjee S, Borek D, Cole AR, Kim PJ, Basler $\mathrm{CF}$, Otwinowski Z, Gross ML, Amarasinghe GK and Leung DW. Structural basis for IFN antagonism by human respiratory syncytial virus nonstructural protein 2. Proc Natl Acad Sci U S A. 2021; 118(10).

9. Gilman MSA, Liu C, Fung A, Behera I, Jordan P, Rigaux P, Ysebaert N, Tcherniuk S, Sourimant J, Eléouët JF, Sutto-Ortiz P, Decroly E, Roymans D, Jin Z and McLellan JS. Structure of the Respiratory Syncytial Virus Polymerase Complex. Cell. 2019; 179(1):193-204.e114.

10. Grosfeld H, Hill MG and Collins PL. RNA replication by respiratory syncytial virus (RSV) is directed by the N, P, and L proteins; transcription also occurs under these conditions but requires RSV superinfection for efficient synthesis of full-length mRNA. J Virol. 1995; 69(9):5677-5686.

11. Galloux M, Gabiane G, Sourimant J, Richard CA, England P, Moudjou M, Aumont-Nicaise M, Fix J, Rameix-Welti MA and Eléouët JF. Identification and characterization of the binding site of the respiratory syncytial virus phosphoprotein to RNA-free nucleoprotein. J Virol. 2015; 89(7):3484-3496.

12. Gan SW, Tan E, Lin X, Yu D, Wang J, Tan GM, Vararattanavech A, Yeo $\mathrm{CY}$, Soon $\mathrm{CH}$, Soong TW, Pervushin $\mathrm{K}$ and Torres J. The small hydrophobic protein of the human respiratory syncytial virus forms pentameric ion channels. The Journal of biological chemistry. 2012; 287(29):24671-24689.

13. Wertz GW, Collins PL, Huang Y, Gruber C, Levine S and Ball LA. Nucleotide sequence of the $G$ protein gene of human respiratory syncytial virus reveals an unusual type of viral membrane protein. Proc Natl Acad Sci U S A. 1985; 82(12):4075-4079.

14. Bukreyev A, Yang L and Collins PL. The secreted G protein of human respiratory syncytial virus antagonizes antibody-mediated restriction of replication involving macrophages and complement. J Virol. 2012; 86(19):10880-10884.

15. Bukreyev A, Yang L, Fricke J, Cheng L, Ward JM, Murphy BR and Collins PL. The secreted form of respiratory syncytial virus G glycoprotein helps the virus evade antibody-mediated restriction of replication by acting as an antigen decoy and through effects on Fc receptor-bearing leukocytes. J Virol. 2008; 82(24):12191-12204.

16. Roberts SR, Lichtenstein D, Ball LA and Wertz GW. The membrane-associated and secreted forms of the respiratory syncytial virus attachment glycoprotein $G$ are synthesized from alternative initiation codons. J Virol. 1994; 68(7):4538-4546.

17. Gorman JJ, Ferguson BL, Speelman D and Mills J. Determination of the disulfide bond arrangement of human respiratory syncytial virus attachment $(\mathrm{G})$ protein by matrix-assisted laser desorption/ionization time-of-flight mass spectrometry. Protein Sci. 1997; 6(6):1308-1315.

18. Langedijk JP, Schaaper WM, Meloen RH and van Oirschot JT. Proposed three-dimensional model for the attachment protein $G$ of respiratory syncytial virus. J Gen Virol. 1996; 77 ( Pt 6):1249-1257.

19. Day ND, Branigan PJ, Liu C, Gutshall LL, Luo J, Melero JA, Sarisky RT and Del Vecchio AM. Contribution of cysteine residues in the extracellular domain of the $\mathrm{F}$ protein of human respiratory syncytial virus to its function. Virol J. 2006; 3:34.

20. Fearns R and Collins PL. Role of the M2-1 transcription antitermination protein of respiratory syncytial virus in sequential transcription. J Virol. 1999; 73(7):5852-5864.

21. Cressey TN, Noton SL, Nagendra K, Braun MR and Fearns $R$. Mechanism for de novo initiation at two sites in the respiratory syncytial virus promoter. Nucleic Acids Res. 2018; 46(13):6785-6796.

22. Techaarpornkul S, Barretto $\mathrm{N}$ and Peeples ME. Functional analysis of recombinant respiratory syncytial virus deletion mutants lacking the small hydrophobic and/or attachment glycoprotein gene. J Virol. 2001; 75(15):6825-6834.

23. Tressler RJ, Updyke TV, Yeatman T and Nicolson GL. Extracellular annexin II is associated with divalent cation-dependent tumor cell-endothelial cell adhesion of metastatic RAW117 large-cell lymphoma cells. J Cell Biochem. 1993; 53(3):265-276.

24. Chung CY, Murphy-Ullrich JE and Erickson HP. Mitogenesis, cell migration, and loss of focal adhesions induced by tenascin-C interacting with its cell surface receptor, annexin II. Mol Biol Cell. 1996; 7(6):883-892.

25. Malhotra R, Ward M, Bright H, Priest R, Foster Martyn R, Hurle M, Blair $\mathrm{E}$ and Bird $\mathrm{M}$. Isolation and characterisation of potential respiratory syncytial virus receptor(s) on epithelial cells. Microbes Infect. 2003; 5(2):123-133.

26. San-Juan-Vergara H, Sampayo-Escobar V, Reyes N, Cha B, Pacheco-Lugo L, Wong T, Peeples ME, Collins PL, Castaño ME and Mohapatra SS. Cholesterol-rich microdomains as docking platforms for respiratory syncytial virus in normal human bronchial epithelial cells. J Virol. 2012; 86(3):1832-1843. 
27. King T, Mejias A, Ramilo O and Peeples ME. The larger attachment glycoprotein of respiratory syncytial virus produced in primary human bronchial epithelial cultures reduces infectivity for cell lines. PLoS Pathog. 2021; 17(4):e1009469.

28. Hallak LK, Spillmann D, Collins PL and Peeples ME. Glycosaminoglycan Sulfation Requirements for Respiratory Syncytial Virus Infection. J. Virol. 2000; 74(22):10508-10513.

29. Johnson SM, McNally BA, Ioannidis I, Flano E, Teng MN, Oomens AG, Walsh EE and Peeples ME. Respiratory Syncytial Virus Uses CX3CR1 as a Receptor on Primary Human Airway Epithelial Cultures. PLoS Pathog. 2015; 11(12):e1005318.

30. Molteni M, Gemma S and Rossetti C. The Role of Toll-Like Receptor 4 in Infectious and Noninfectious Inflammation. Mediators Inflamm. 2016; 2016:6978936

31. Kurt-Jones EA, Popova L, Kwinn L, Haynes LM, Jones LP, Tripp RA, Walsh EE, Freeman MW, Golenbock DT, Anderson LJ and Finberg RW. Pattern recognition receptors TLR4 and CD14 mediate response to respiratory syncytial virus. Nature Immunology. 2000; 1(5):398-401.

32. Behera AK, Matsuse $H$, Kumar M, Kong X, Lockey RF and Mohapatra SS. Blocking intercellular adhesion molecule-1 on human epithelial cells decreases respiratory syncytial virus infection. Biochem Biophys Res Commun. 2001; 280(1):188-195.

33. Currier MG, Lee S, Stobart CC, Hotard AL, Villenave R, Meng J, Pretto CD, Shields MD, Nguyen MT, Todd SO, Chi MH, Hammonds J, Krumm SA, Spearman P, Plemper RK, Sakamoto K, Peebles RS, Jr., Power UF and Moore ML. EGFR Interacts with the Fusion Protein of Respiratory Syncytial Virus Strain 2-20 and Mediates Infection and Mucin Expression. PLoS Pathog. 2016; 12(5):e1005622.

34. Tayyari F, Marchant D, Moraes TJ, Duan W, Mastrangelo P and Hegele RG. Identification of nucleolin as a cellular receptor for human respiratory syncytial virus. Nat Med. 2011; 17(9):1132-1135.

35. Nisole S, Said EA, Mische C, Prevost MC, Krust B, Bouvet P, Bianco A, Briand JP and Hovanessian AG. The anti-HIV pentameric pseudopeptide HB-19 binds the C-terminal end of nucleolin and prevents anchorage of virus particles in the plasma membrane of target cells. The Journal of biological chemistry. 2002; 277(23):20877-20886.

36. Bose S, Basu M and Banerjee AK. Role of nucleolin in human parainfluenza virus type 3 infection of human lung epithelial cells. J Virol. 2004; 78(15):8146-8158.

37. Su PY, Wang YF, Huang SW, Lo YC, Wang YH, Wu SR, Shieh DB, Chen $\mathrm{SH}$, Wang JR, Lai MD and Chang CF. Cell surface nucleolin facilitates enterovirus 71 binding and infection. J Virol. 2015; 89(8):4527-4538.

38. Chan CM, Chu H, Zhang AJ, Leung LH, Sze KH, Kao RY, Chik KK, To KK, Chan JF, Chen H, Jin DY, Liu L and Yuen KY. Hemagglutinin of influenza A virus binds specifically to cell surface nucleolin and plays a role in virus internalization. Virology. 2016; 494:78-88.

39. Zhu J, Miao Q, Tang J, Wang X, Dong D, Liu T, Qi R, Yang Z and Liu G. Nucleolin mediates the internalization of rabbit hemorrhagic disease virus through clathrin-dependent endocytosis. PLoS Pathog. 2018; 14(10):e1007383.

40. Griffiths CD, Bilawchuk LM, McDonough JE, Jamieson KC, Elawar F, Cen Y, Duan W, Lin C, Song H, Casanova J-L, Ogg S, Jensen LD, Thienpont B, Kumar A, Hobman TC, Proud D, Moraes TJ and Marchant DJ. IGF1R is an entry receptor for respiratory syncytial virus. Nature. 2020; 583(7817):615-619.

41. Lingemann M, McCarty T, Liu X, Buchholz UJ, Surman S, Martin SE, Collins PL and Munir S. The alpha-1 subunit of the $\mathrm{Na}+, \mathrm{K}+-\mathrm{ATPase}$ (ATP1A1) is required for macropinocytic entry of respiratory syncytial virus (RSV) in human respiratory epithelial cells. PLoS Pathog. 2019; 15(8):e1007963.

42. Krzyzaniak MA, Zumstein MT, Gerez JA, Picotti P and Helenius A. Host cell entry of respiratory syncytial virus involves macropinocytosis followed by proteolytic activation of the F protein. PLoS Pathog. 2013; 9(4):e1003309.

43. Rincheval V, Lelek M, Gault E, Bouillier C, Sitterlin D, Blouquit-Laye S, Galloux M, Zimmer C, Eleouet JF and Rameix-Welti MA. Functional organization of cytoplasmic inclusion bodies in cells infected by respiratory syncytial virus. Nat Commun. 2017; 8(1):563.

44. Lifland AW, Jung J, Alonas E, Zurla C, Crowe JE, Jr. and Santangelo PJ. Human respiratory syncytial virus nucleoprotein and inclusion bodies antagonize the innate immune response mediated by MDA5 and MAVS. J Virol. 2012; 86(15):8245-8258.

45. Brown G, Rixon HW, Steel J, McDonald TP, Pitt AR, Graham S and Sugrue RJ. Evidence for an association between heat shock protein 70 and the respiratory syncytial virus polymerase complex within lipid-raft membranes during virus infection. Virology. 2005; 338(1):69-80.

46. Bermingham A and Collins PL. The M2-2 protein of human respiratory syncytial virus is a regulatory factor involved in the balance between
RNA replication and transcription. Proc Natl Acad Sci U S A. 1999; 96(20):11259-11264.

47. Noton SL, Tremaglio CZ and Fearns R. Killing two birds with one stone: How the respiratory syncytial virus polymerase initiates transcription and replication. PLoS Pathog. 2019; 15(2):e1007548.

48. Fearns R. The Respiratory Syncytial Virus Polymerase: A Multitasking Machine. Trends Microbiol. 2019; 27(12):969-971.

49. Vanover D, Smith DV, Blanchard EL, Alonas E, Kirschman JL, Lifland AW, Zurla C and Santangelo PJ. RSV glycoprotein and genomic RNA dynamics reveal filament assembly prior to the plasma membrane. Nat Commun. 2017; 8(1):667.

50. Roberts PC and Compans RW. Host cell dependence of viral morphology. Proc Natl Acad Sci U S A. 1998; 95(10):5746-5751.

51. Dey R, Folkins MA and Ashbolt NJ. Extracellular amoebal-vesicles: potential transmission vehicles for respiratory viruses. npj Biofilms and Microbiomes. 2021; 7(1):25.

52. Hu M, Schulze KE, Ghildyal R, Henstridge DC, Kolanowski JL, New EJ, Hong Y, Hsu AC, Hansbro PM, Wark PA, Bogoyevitch MA and Jans DA. Respiratory syncytial virus co-opts host mitochondrial function to favour infectious virus production. eLife. 2019; 8.

53. Morris DR, Qu Y, Agrawal A, Garofalo RP and Casola A. HIF-1a Modulates Core Metabolism and Virus Replication in Primary Airway Epithelial Cells Infected with Respiratory Syncytial Virus. Viruses. 2020; 12(10).

54. Kalinowski A, Galen BT, Ueki IF, Sun Y, Mulenos A, Osafo-Addo A, Clark B, Joerns J, Liu W, Nadel JA, Dela Cruz CS and Koff JL. Respiratory syncytial virus activates epidermal growth factor receptor to suppress interferon regulatory factor 1-dependent interferon-lambda and antiviral defense in airway epithelium. Mucosal Immunol. 2018; 11(3):958-967.

55. Thornhill EM and Verhoeven D. Respiratory Syncytial Virus's Non-structural Proteins: Masters of Interference. Frontiers in cellular and infection microbiology. 2020; 10(225).

56. Goswami R, Majumdar T, Dhar J, Chattopadhyay S, Bandyopadhyay SK, Verbovetskaya V, Sen GC and Barik S. Viral degradasome hijacks mitochondria to suppress innate immunity. Cell Res. 2013; 23(8):1025-1042.

57. Swedan S, Musiyenko A and Barik S. Respiratory Syncytial Virus Nonstructural Proteins Decrease Levels of Multiple Members of the Cellular Interferon Pathways. J. Virol. 2009; 83(19):9682-9693.

58. Elliott J, Lynch OT, Suessmuth Y, Qian P, Boyd CR, Burrows JF, Buick R, Stevenson NJ, Touzelet O, Gadina M, Power UF and Johnston JA. Respiratory Syncytial Virus NS1 Protein Degrades STAT2 by Using the Elongin-Cullin E3 Ligase. J. Virol. 2007; 81(7):3428-3436.

59. Munir S, Hillyer P, Le Nouën C, Buchholz UJ, Rabin RL, Collins PL and Bukreyev A. Respiratory Syncytial Virus Interferon Antagonist NS1 Protein Suppresses and Skews the Human T Lymphocyte Response. PLoS Pathog. 2011; 7(4):e1001336.

60. Wu YH, Lai AC, Chi PY, Thio CL, Chen WY, Tsai CH, Lee YL, Lukacs NW and Chang YJ. Pulmonary IL-33 orchestrates innate immune cells to mediate respiratory syncytial virus-evoked airway hyperreactivity and eosinophilia. Allergy. 2020; 75(4):818-830.

61. Warren KJ, Poole JA, Sweeter JM, DeVasure JM, Dickinson JD, Peebles RS and Wyatt TA. Neutralization of IL-33 modifies the type 2 and type 3 inflammatory signature of viral induced asthma exacerbation. Respiratory Research. 2021; 22(1):206.

62. Zhang L, Wan $\mathrm{Y}$, Ma L, Xu K and Cheng $\mathrm{B}$. Inhibition of NF-kB/IL-33/ST2 Axis Ameliorates Acute Bronchiolitis Induced by Respiratory Syncytial Virus. Journal of Immunology Research. 2021; 2021:6625551.

63. Saravia J, You D, Shrestha B, Jaligama S, Siefker D, Lee GI, Harding JN, Jones TL, Rovnaghi C, Bagga B, DeVincenzo JP and Cormier SA. Respiratory Syncytial Virus Disease Is Mediated by Age-Variable IL-33. PLoS Pathog. 2015; 11(10):e1005217.

64. Qi F, Bai S, Wang D, Xu L, Hu H, Zeng S, Chai R and Liu B. Macrophages produce IL-33 by activating MAPK signaling pathway during RSV infection. Molecular Immunology. 2017; 87:284-292.

65. Tsai CH, Wu AC, Chiang BL, Yang YH, Hung SP, Su MW, Chang YJ and Lee YL. CEACAM3 decreases asthma exacerbations and modulates respiratory syncytial virus latent infection in children. Thorax. 2020; 75(9):725-734

66. Sande CJ, Njunge JM, Mwongeli Ngoi J, Mutunga MN, Chege T, Gicheru ET, Gardiner EM, Gwela A, Green CA, Drysdale SB, Berkley JA, Nokes DJ and Pollard AJ. Airway response to respiratory syncytial virus has incidental antibacterial effects. Nat Commun. 2019; 10(1):2218.

67. Efstathiou C, Abidi SH, Harker J and Stevenson NJ. Revisiting respiratory syncytial virus's interaction with host immunity, towards novel therapeutics. Cellular and molecular life sciences : CMLS. 2020; 77(24):5045-5058 
68. Thwaites RS and Openshaw PJ. The Respiratory Mucosa: Front and Center in Respiratory Syncytial Virus Disease. American journal of respiratory and critical care medicine. 2019; 200(11):1340-1342.

69. Kim MJ, Shim DH, Cha HR, Moon KY, Yang CM, Hwang SJ, Kim KW, Park JH, Lee CG, Elias JA, Sohn MH and Lee JM. Chitinase 3-like 1 protein plays a critical role in respiratory syncytial virus-induced airway inflammation. Allergy. 2019; 74(4):685-697.

70. Thwaites RS, Coates M, Ito K, Ghazaly M, Feather C, Abdulla F, Tunstall T, Jain P, Cass L, Rapeport G, Hansel TT, Nadel S and Openshaw P. Reduced Nasal Viral Load and IFN Responses in Infants with Respiratory Syncytial Virus Bronchiolitis and Respiratory Failure. American journal of respiratory and critical care medicine. 2018; 198(8):1074-1084.

71. Heinonen S, Velazquez VM, Ye F, Mertz S, Acero-Bedoya S, Smith B, Bunsow E, Garcia-Mauriño C, Oliva S, Cohen DM, Moore-Clingenpeel $\mathrm{M}$, Peeples ME, Ramilo $\mathrm{O}$ and Mejias A. Immune profiles provide insights into respiratory syncytial virus disease severity in young children. Sci Transl Med. 2020; 12(540).

72. Gassen RB, Fazolo T, Nascimento de Freitas D, Borges TJ, Lima K, Antunes GL, Maito F, Bueno Mendes DA, Báfica A, Rodrigues LC, Jr., Stein R, Duarte de Souza AP and Bonorino C. IL-21 treatment recovers follicular helper $\mathrm{T}$ cells and neutralizing antibody production in respiratory syncytial virus infection. Immunol Cell Biol. 2020.

73. van Erp EA, Lakerveld AJ, de Graaf E, Larsen MD, Schepp RM, Hipgrave Ederveen AL, Ahout IM, de Haan CA, Wuhrer M, Luytjes W, Ferwerda G, Vidarsson G and van Kasteren PB. Natural killer cell activation by respiratory syncytial virus-specific antibodies is decreased in infants with severe respiratory infections and correlates with Fc-glycosylation. Clin Transl Immunology. 2020; 9(2):e1112.

74. de Steenhuijsen Piters WA, Heinonen S, Hasrat R, Bunsow E, Smith B, Suarez-Arrabal MC, Chaussabel D, Cohen DM, Sanders EA, Ramilo O, Bogaert D and Mejias A. Nasopharyngeal Microbiota, Host Transcriptome, and Disease Severity in Children with Respiratory Syncytial Virus Infection. American journal of respiratory and critical care medicine. 2016; 194(9):1104-1115.

75. Thorburn K, Harigopal S, Reddy V, Taylor N and van Saene HK. High incidence of pulmonary bacterial co-infection in children with severe respiratory syncytial virus (RSV) bronchiolitis. Thorax. 2006; 61(7):611-615.

76. Yeo KT, Yung CF, Khoo PC, Saffari SE, Sng JSP, How MS and Quek BH. Effectiveness of Palivizumab against Respiratory Syncytial Virus Hospitalization among Preterm Infants in a Setting with Year-round Circulation. The Journal of infectious diseases. 2020.

77. Cingoz O. Motavizumab. mAbs. 2009; 1(5):439-442.

78. Dall'Acqua WF, Kiener PA and Wu H. Properties of human IgG1s engineered for enhanced binding to the neonatal $\mathrm{Fc}$ receptor ( $\mathrm{FcRn})$. The Journal of biological chemistry. 2006; 281(33):23514-23524.

79. Kwakkenbos MJ, Diehl SA, Yasuda E, Bakker AQ, van Geelen CM, Lukens MV, van Bleek GM, Widjojoatmodjo MN, Bogers WM, Mei H, Radbruch A, Scheeren FA, Spits H and Beaumont T. Generation of stable monoclonal antibody-producing $B$ cell receptor-positive human memory B cells by genetic programming. Nat Med. 2010; 16(1):123-128.

80. Griffin MP, Khan AA, Esser MT, Jensen K, Takas T, Kankam MK, Villafana T and Dubovsky F. Safety, Tolerability, and Pharmacokinetics of MEDI8897, the Respiratory Syncytial Virus Prefusion F-Targeting Monoclonal Antibody with an Extended Half-Life, in Healthy Adults. Antimicrob Agents Chemother. 2017; 61(3).

81. Domachowske JB, Khan AA, Esser MT, Jensen K, Takas T, Villafana T, Dubovsky F and Griffin MP. Safety, Tolerability and Pharmacokinetics of MEDI8897, an Extended Half-life Single-dose Respiratory Syncytial Virus Prefusion F-targeting Monoclonal Antibody Administered as a Single Dose to Healthy Preterm Infants. Pediatr Infect Dis J. 2018; 37(9):886-892

82. Griffin MP, Yuan $\mathrm{Y}$, Takas T, Domachowske JB, Madhi SA, Manzoni P, Simões EAF, Esser MT, Khan AA, Dubovsky F, Villafana $\mathrm{T}$ and DeVincenzo JP. Single-Dose Nirsevimab for Prevention of RSV in Preterm Infants. N. Engl. J. Med. 2020; 383(5):415-425.

83. Sivapalasingam S, Caballero-Perez D, Houghton M, Yang F, Davis J, Gao B and Geba G. Phase 1 Study Evaluating Safety, Tolerability, Pharmacokinetics and Immunogenicity of REGN2222 in Healthy Adults: A New Human Monoclonal RSV-F Antibody for RSV Prevention. Open Forum Infectious Diseases. 2015; 2(suppl_1).

84. Simões EAF, Forleo-Neto E, Geba GP, Kamal M, Yang F, Cicirello H, Houghton MR, Rideman R, Zhao Q, Benvin SL, Hawes A, Fuller ED, Wloga E, Pizarro JMN, Munoz FM, Rush SA, McLellan JS, Lipsich L, Stahl N, Yancopoulos GD, Weinreich DM, Kyratsous CA and Sivapalasingam S. Suptavumab for the Prevention of Medically Attended Respiratory Syncytial Virus Infection in Preterm Infants.
Clinical infectious diseases : an official publication of the Infectious Diseases Society of America. 2020.

85. Tang A, Chen Z, Cox KS, Su H-P, Callahan C, Fridman A, Zhang L, Patel SB, Cejas PJ, Swoyer R, Touch S, Citron MP, Govindarajan D, Luo B, Eddins M, Reid JC, Soisson SM, Galli J, Wang D, Wen Z, Heidecker GJ, Casimiro DR, DiStefano DJ and Vora KA. A potent broadly neutralizing human RSV antibody targets conserved site IV of the fusion glycoprotein. Nat. Commun. 2019; 10(1):4153.

86. Corti D, Bianchi S, Vanzetta F, Minola A, Perez L, Agatic G, Guarino B, Silacci C, Marcandalli J, Marsland BJ, Piralla A, Percivalle E, Sallusto F, Baldanti F and Lanzavecchia A. Cross-neutralization of four paramyxoviruses by a human monoclonal antibody. Nature. 2013; 501(7467):439-443.

87. Detalle L, Stohr T, Palomo C, Piedra PA, Gilbert BE, Mas V, Millar A, Power UF, Stortelers C, Allosery K, Melero JA and Depla E. Generation and Characterization of ALX-0171, a Potent Novel Therapeutic Nanobody for the Treatment of Respiratory Syncytial Virus Infection. Antimicrobial Agents and Chemotherapy. 2016; 60(1):6-13.

88. Cunningham S, Piedra PA, Martinon-Torres F, Szymanski H, Brackeva B, Dombrecht E, Detalle L and Fleurinck C. Nebulised ALX-0171 for respiratory syncytial virus lower respiratory tract infection in hospitalised children: a double-blind, randomised, placebo-controlled, phase $2 b$ trial. The Lancet. Respiratory medicine. 2021; 9(1):21-32.

89. Rossey I, Gilman MS, Kabeche SC, Sedeyn K, Wrapp D, Kanekiyo M, Chen M, Mas V, Spitaels J, Melero JA, Graham BS, Schepens B, McLellan JS and Saelens $X$. Potent single-domain antibodies that arrest respiratory syncytial virus fusion protein in its prefusion state. Nat Commun. 2017; 8:14158.

90. Tiwari PM, Vanover D, Lindsay KE, Bawage SS, Kirschman JL, Bhosle S, Lifland AW, Zurla C and Santangelo PJ. Engineered mRNA-expressed antibodies prevent respiratory syncytial virus infection. Nat Commun. 2018; 9(1):3999.

91. Fedechkin SO, George NL, Wolff JT, Kauvar LM and DuBois RM. Structures of respiratory syncytial virus $\mathrm{G}$ antigen bound to broadly neutralizing antibodies. Sci Immunol. 2018; 3(21).

92. Collarini EJ, Lee FE-H, Foord O, Park M, Sperinde G, Wu H, Harriman WD, Carroll SF, Ellsworth SL, Anderson LJ, Tripp RA, Walsh EE, Keyt BA and Kauvar LM. Potent High-Affinity Antibodies for Treatment and Prophylaxis of Respiratory Syncytial Virus Derived from B Cells of Infected Patients. The Journal of Immunology. 2009; 183(10):6338-6345.

93. Anderson LJ, Bingham P and Hierholzer JC. Neutralization of respiratory syncytial virus by individual and mixtures of $F$ and $G$ protein monoclonal antibodies. J Virol. 1988; 62(11):4232-4238.

94. Lee H-J, Lee J-Y, Park M-H, Kim J-Y and Chang J. Monoclonal Antibody against G Glycoprotein Increases Respiratory Syncytial Virus Clearance In vivo and Prevents Vaccine-Enhanced Diseases. PLoS One. 2017; 12(1):e0169139.

95. Lee J, Klenow L, Coyle EM, Golding H and Khurana S. Protective antigenic sites in respiratory syncytial virus $G$ attachment protein outside the central conserved and cysteine noose domains. PLoS Pathog. 2018; 14(8):e1007262.

96. Kwakkenbos MJ, Diehl SA, Yasuda E, Bakker AQ, van Geelen CMM, Lukens MV, van Bleek GM, Widjojoatmodjo MN, Bogers WMJM, Mei H, Radbruch A, Scheeren FA, Spits $\mathrm{H}$ and Beaumont T. Generation of stable monoclonal antibody-producing $B$ cell receptor-positive human memory B cells by genetic programming. Nature Medicine. 2010; 16(1):123-128.

97. Polack FP, Teng MN, Collins PL, Prince GA, Exner M, Regele H, Lirman DD, Rabold R, Hoffman SJ, Karp CL, Kleeberger SR, Wills-Karp M and Karron RA. A role for immune complexes in enhanced respiratory syncytial virus disease. The Journal of experimental medicine. 2002; 196(6):859-865.

98. Graham BS. Immunological goals for respiratory syncytial virus vaccine development. Curr Opin Immunol. 2019; 59:57-64.

99. Yamin D, Jones FK, DeVincenzo JP, Gertler S, Kobiler O, Townsend JP and Galvani AP. Vaccination strategies against respiratory syncytial virus. Proc Natl Acad Sci U S A. 2016; 113(46):13239-13244.

100. Karron RA, Luongo C, Thumar B, Loehr KM, Englund JA, Collins PL and Buchholz UJ. A gene deletion that up-regulates viral gene expression yields an attenuated RSV vaccine with improved antibody responses in children. Sci Transl Med. 2015; 7(312):312ra175.

101. McFarland EJ, Karron RA, Muresan P, Cunningham CK, Valentine ME Perlowski C, Thumar B, Gnanashanmugam D, Siberry GK, Schappell E, Barr E, Rexroad V, Yogev R, Spector SA, Aziz M, Patel N, Cielo M, Luongo C, Collins PL, Buchholz UJ and Team IMPAACTS. Live-Attenuated Respiratory Syncytial Virus Vaccine Candidate With Deletion of RNA Synthesis Regulatory Protein M2-2 is Highly Immunogenic in Children. The Journal of infectious diseases. 2018; 217(9):1347-1355 
102. McFarland EJ, Karron RA, Muresan P, Cunningham CK, Libous J, Perlowski C, Thumar B, Gnanashanmugam D, Moye J, Jr, Schappell E, Barr E, Rexroad V, Fearn L, Spector SA, Aziz M, Cielo M, Beneri C, Wiznia A, Luongo C, Collins P, Buchholz UJ and Team tIMPAACTS. Live Respiratory Syncytial Virus Attenuated by M2-2 Deletion and Stabilized Temperature Sensitivity Mutation 1030s Is a Promising Vaccine Candidate in Children. The Journal of infectious diseases. 2019; 221(4):534-543.

103. McFarland EJ, Karron RA, Muresan P, Cunningham CK, Perlowski C, Libous J, Oliva J, Jean-Philippe P, Moye J, Jr, Schappell E, Barr E, Rexroad V, Fearn L, Cielo M, Wiznia A, Deville JG, Yang L, Luongo C, Collins PL, Buchholz UJ and Team tIMPAACTS. Live-Attenuated Respiratory Syncytial Virus Vaccine With M2-2 Deletion and With Small Hydrophobic Noncoding Region Is Highly Immunogenic in Children. The Journal of infectious diseases. 2020; 221(12):2050-2059.

104. Jenkins T, Wang R, Harder O, Xue M, Chen P, Corry J, Walker C, Teng M, Mejias A, Ramilo O, Niewiesk S, Li J and Peeples ME. A Novel Live Attenuated Respiratory Syncytial Virus Vaccine Candidate with Mutations in the L Protein SAM Binding Site and the G Protein Cleavage Site Is Protective in Cotton Rats and a Rhesus Macaque. J Virol. 2021; 95(3)

105. Shang Z, Chan SY, Liu WJ, Li P and Huang W. Recent Insights into Emerging Coronavirus: SARS-CoV-2. ACS infectious diseases. 2020.

106. Ruckwardt TJ, Morabito KM, Phung E, Crank MC, Costner PJ, Holman LA, Chang LA, Hickman SP, Berkowitz NM, Gordon IJ, Yamshchikov GV, Gaudinski MR, Lin B, Bailer R, Chen M, Ortega-Villa AM, Nguyen T, Kumar A, Schwartz RM, Kueltzo LA, Stein JA, Carlton K, Gall JG, Nason MC, Mascola JR, Chen G and Graham BS. Safety, tolerability, and immunogenicity of the respiratory syncytial virus prefusion $\mathrm{F}$ subunit vaccine DS-Cav1: a phase 1, randomised, open-label, dose-escalation clinical trial. The Lancet. Respiratory medicine. 2021.

107. GSK. 202025 April. GSK presents positive clinical data on maternal and older adults RSV candidate vaccines. <https://us.gsk.com/en-us/ media/press-releases/gsk-presents-positive-clinical-data-on-maternal-a nd-older-adults-rsv-candidate-vaccines $>$. Accessed 202125 April.

108. Madhi SA, Polack FP, Piedra PA, Munoz FM, Trenholme AA, Simões EAF, Swamy GK, Agrawal S, Ahmed K, August A, Baqui AH, Calvert A, Chen J, Cho I, Cotton MF, Cutland CL, Englund JA, Fix A, Gonik B, Hammitt L, Heath PT, de Jesus JN, Jones CE, Khalil A, Kimberlin DW, Libster R, Llapur CJ, Lucero M, Pérez Marc G, Marshall HS, Masenya MS, Martinón-Torres F, Meece JK, Nolan TM, Osman A, Perrett KP, Plested JS, Richmond PC, Snape MD, Shakib JH, Shinde V, Stoney T, Thomas DN, Tita AT, Varner MW, Vatish M, Vrbicky K, Wen J, Zaman K, Zar HJ, Glenn GM and Fries LF. Respiratory Syncytial Virus Vaccination during Pregnancy and Effects in Infants. The New England journal of medicine. 2020; 383(5):426-439.

109. Andreano E, Paciello I, Bardelli M, Tavarini S, Sammicheli C, Frigimelica E, Guidotti S, Torricelli G, Biancucci M, D'Oro U, Chandramouli S, Bottomley MJ, Rappuoli R, Finco O and Buricchi F. The respiratory syncytial virus (RSV) prefusion F-protein functional antibody repertoire in adult healthy donors. EMBO Mol Med. 2021:e14035.

110. Langley JM, MacDonald LD, Weir GM, MacKinnon-Cameron D, Ye L, McNeil S, Schepens B, Saelens X, Stanford MM and Halperin SA. A Respiratory Syncytial Virus Vaccine Based on the Small Hydrophobic Protein Ectodomain Presented With a Novel Lipid-Based Formulation Is Highly Immunogenic and Safe in Adults: A First-in-Humans Study. The Journal of infectious diseases. 2018; 218(3):378-387.

111. Hervé PL, Descamps D, Deloizy C, Dhelft V, Laubreton D, Bouguyon E, Boukadiri A, Dubuquoy C, Larcher T, Benhamou PH, Eléouët JF, Bertho $\mathrm{N}$, Mondoulet L and Riffault S. Non-invasive epicutaneous vaccine against Respiratory Syncytial Virus: Preclinical proof of concept. Journal of controlled release : official journal of the Controlled Release Society. 2016; 243:146-159.

112. Céspedes PF, Rey-Jurado E, Espinoza JA, Rivera CA, Canedo-Marroquín G, Bueno SM and Kalergis AM. A single, low dose of a cGMP recombinant BCG vaccine elicits protective $\mathrm{T}$ cell immunity against the human respiratory syncytial virus infection and prevents lung pathology in mice. Vaccine. 2017; 35(5):757-766.

113. Marcandalli J, Fiala B, Ols S, Perotti M, de van der Schueren W, Snijder J, Hodge E, Benhaim M, Ravichandran R, Carter L, Sheffler W, Brunner L, Lawrenz M, Dubois P, Lanzavecchia A, Sallusto F, Lee KK, Veesler D, Correnti CE, Stewart LJ, Baker D, Loré K, Perez L and King NP. Induction of Potent Neutralizing Antibody Responses by a Designed Protein Nanoparticle Vaccine for Respiratory Syncytial Virus. Cell. 2019; 176(6):1420-1431.e1417.

114. Swanson KA, Rainho-Tomko JN, Williams ZP, Lanza L, Peredelchuk M, Kishko M, Pavot V, Alamares-Sapuay J, Adhikarla H, Gupta S, Chivukula S, Gallichan S, Zhang L, Jackson N, Yoon H, Edwards D, Wei CJ and Nabel GJ. A respiratory syncytial virus (RSV) F protein nanoparticle vaccine focuses antibody responses to a conserved neutralization domain. Sci Immunol. 2020; 5(47).

115. Widjojoatmodjo MN, Bogaert L, Meek B, Zahn R, Vellinga J, Custers J, Serroyen J, Radošević $\mathrm{K}$ and Schuitemaker $H$. Recombinant low-seroprevalent adenoviral vectors Ad26 and Ad35 expressing the respiratory syncytial virus (RSV) fusion protein induce protective immunity against RSV infection in cotton rats. Vaccine. 2015; 33(41):5406-5414.

116. Sadoff J, De Paepe E, Haazen W, Omoruyi E, Bastian AR, Comeaux C, Heijnen E, Strout C, Schuitemaker $\mathrm{H}$ and Callendret B. Safety and Immunogenicity of the Ad26.RSV.preF Investigational Vaccine Coadministered With an Influenza Vaccine in Older Adults. The Journal of infectious diseases. 2021; 223(4):699-708.

117. Jones BG, Sealy RE, Rudraraju R, Traina-Dorge VL, Finneyfrock B, Cook A, Takimoto T, Portner A and Hurwitz JL. Sendai virus-based RSV vaccine protects African green monkeys from RSV infection. Vaccine. 2012; 30(5):959-968

118. Scaggs Huang F, Bernstein DI, Slobod KS, Portner A, Takimoto T, Russell CJ, Meagher M, Jones BG, Sealy RE, Coleclough C, Branum K, Dickey M, Buschle K, McNeal M, Makowski M, Nakamura A and Hurwitz JL. Safety and immunogenicity of an intranasal sendai virus-based vaccine for human parainfluenza virus type $I$ and respiratory syncytial virus (SeVRSV) in adults. Hum Vaccin Immunother. 2021; 17(2):554-559.

119. Cicconi P, Jones C, Sarkar E, Silva-Reyes L, Klenerman P, de Lara C, Hutchings C, Moris P, Janssens M, Fissette LA, Picciolato M, Leach A, Gonzalez-Lopez A, Dieussaert I and Snape MD. First-in-Human Randomized Study to Assess the Safety and Immunogenicity of an Investigational Respiratory Syncytial Virus (RSV) Vaccine Based on Chimpanzee-Adenovirus-155 Viral Vector-Expressing RSV Fusion, Nucleocapsid, and Antitermination Viral Proteins in Healthy Adults. Clinical infectious diseases : an official publication of the Infectious Diseases Society of America. 2020; 70(10):2073-2081.

120. Volkmann A, Williamson AL, Weidenthaler H, Meyer TPH, Robertson JS, Excler JL, Condit RC, Evans E, Smith ER, Kim D and Chen RT. The Brighton Collaboration standardized template for collection of key information for risk/benefit assessment of a Modified Vaccinia Ankara (MVA) vaccine platform. Vaccine. 2020.

121. Jordan E, Lawrence SJ, Meyer TPH, Schmidt D, Schultz S, Mueller J, Stroukova D, Koenen B, Gruenert R, Silbernagl G, Vidojkovic S, Chen LM, Weidenthaler H, Samy N and Chaplin P. Broad Antibody and Cellular Immune Response From a Phase 2 Clinical Trial With a Novel Multivalent Poxvirus-Based Respiratory Syncytial Virus Vaccine. The Journal of infectious diseases. 2021; 223(6):1062-1072.

122. Espeseth AS, Cejas PJ, Citron MP, Wang D, DiStefano DJ, Callahan C, Donnell GO, Galli JD, Swoyer R, Touch S, Wen Z, Antonello J, Zhang L, Flynn JA, Cox KS, Freed DC, Vora KA, Bahl K, Latham AH, Smith JS, Gindy ME, Ciaramella G, Hazuda D, Shaw CA and Bett AJ. Modified mRNA/lipid based vaccines expressing respiratory syncytial virus F protein variants are immunogenic and protective in rodent models of RSV infection. NPJ vaccines. 2020; 5(1):16.

123. Moderna. Moderna Announces Clinical Progress from its Industry-Leading mRNA Vaccine Franchise and Continues Investments to Accelerate Pipeline Development. 202026 April. https://www.biospace.com/article/releases/moderna-announces-clini cal-progress-from-its-industry-leading-mrna-vaccine-franchise-and-cont inues-investments-to-accelerate-pipeline-development. Accessed 202126 April.

124. Saso A and Kampmann B. Vaccination against respiratory syncytial virus in pregnancy: a suitable tool to combat global infant morbidity and mortality? The Lancet. Infectious diseases. 2016; 16(8):e153-163.

125. Perron M, Stray K, Kinkade A, Theodore D, Lee G, Eisenberg E, Sangi M, Gilbert BE, Jordan R, Piedra PA, Toms GL, Mackman R and Cihlar T. GS-5806 Inhibits a Broad Range of Respiratory Syncytial Virus Clinical Isolates by Blocking the Virus-Cell Fusion Process. Antimicrobial Agents and Chemotherapy. 2016; 60(3):1264-1273.

126. DeVincenzo JP, Whitley RJ, Mackman RL, Scaglioni-Weinlich C, Harrison L, Farrell E, McBride S, Lambkin-Williams R, Jordan R, Xin Y, Ramanathan S, O'Riordan T, Lewis SA, Li X, Toback SL, Lin S-L and Chien JW. Oral GS-5806 Activity in a Respiratory Syncytial Virus Challenge Study. N. Engl. J. Med. 2014; 371(8):711-722.

127. Marty FM, Chemaly RF, Mullane KM, Lee DG, Hirsch HH, Small CB, Bergeron A, Shoham S, Ljungman P, Waghmare A, Blanchard E, Kim YJ, McKevitt M, Porter DP, Jordan R, Guo Y, German P, Boeckh M, Watkins TR, Chien JW and Dadwal SS. A Phase 2b, Randomized, Double-blind, Placebo-Controlled Multicenter Study Evaluating Antiviral Effects, Pharmacokinetics, Safety, and Tolerability of Presatovir in Hematopoietic Cell Transplant Recipients with Respiratory Syncytial 
Virus Infection of the Lower Respiratory Tract. Clinical infectious diseases : an official publication of the Infectious Diseases Society of America. 2020; 71(11):2787-2795.

128. Elawar F, Oraby AK, Kieser Q, Jensen LD, Culp T, West FG and Marchant DJ. Pharmacological targets and emerging treatments for respiratory syncytial virus bronchiolitis. Pharmacol Ther. 2020:107712.

129. Roymans D, Alnajjar SS, Battles MB, Sitthicharoenchai $P$, Furmanova-Hollenstein P, Rigaux P, Berg JVD, Kwanten L, Ginderen MV, Verheyen N, Vranckx L, Jaensch S, Arnoult E, Voorzaat R, Gallup JM, Larios-Mora A, Crabbe M, Huntjens D, Raboisson P, Langedijk JP, Ackermann MR, McLellan JS, Vendeville S and Koul A. Therapeutic efficacy of a respiratory syncytial virus fusion inhibitor. Nat Commun. 2017; 8(1):167.

130. Challa S, Scott AD, Yuzhakov O, Zhou Y, Tiong-Yip CL, Gao N, Thresher $\mathrm{J}$ and $\mathrm{Yu} \mathrm{Q}$. Mechanism of action for respiratory syncytial virus inhibitor RSV604. Antimicrob Agents Chemother. 2015; 59(2):1080-1087.

131. Rhodin MHJ, McAllister NV, Castillo J, Noton SL, Fearns R, Kim IJ, Yu J, Blaisdell TP, Panarese I, Shook BC, Or YS, Goodwin B and Lin K. EDP-938, a novel nucleoprotein inhibitor of respiratory syncytial virus, demonstrates potent antiviral activities in vitro and in a non-human primate model. PLoS Pathog. 2021; 17(3):e1009428.

132. DeVincenzo J, Lambkin-Williams R, Wilkinson T, Cehelsky J, Nochur S, Walsh E, Meyers R, Gollob J and Vaishnaw A. A randomized, double-blind, placebo-controlled study of an RNAi-based therapy directed against respiratory syncytial virus. Proc Natl Acad Sci U S A. 2010; 107(19):8800-8805.

133. Gottlieb J, Zamora MR, Hodges T, Musk AW, Sommerwerk U, Dilling D, Arcasoy S, DeVincenzo J, Karsten V, Shah S, Bettencourt BR, Cehelsky J, Nochur S, Gollob J, Vaishnaw A, Simon AR and Glanville AR. ALN-RSV01 for prevention of bronchiolitis obliterans syndrome after respiratory syncytial virus infection in lung transplant recipients. J Heart Lung Transplant. 2016; 35(2):213-221.

134. Pearson H, Todd E, Ahrends M, Hover SE, Whitehouse A, Stacey M, Lippiat JD, Wilkens L, Fieguth HG, Danov O, Hesse C, Barr JN and Mankouri J. TMEM16A/ANO1 calcium-activated chloride channel as a novel target for the treatment of human respiratory syncytial virus infection. Thorax. 2021; 76(1):64-72.

135. Risso-Ballester J, Galloux M, Cao J, Le Goffic R, Hontonnou F, Jobart-Malfait A, Desquesnes A, Sake SM, Haid S, Du M, Zhang X, Zhang H, Wang Z, Rincheval V, Zhang Y, Pietschmann T, Eléouët J-F, Rameix-Welti M-A and Altmeyer R. A condensate-hardening drug blocks RSV replication in vivo. Nature. 2021; 595(7868):596-599. 